\title{
Impacts of East Mediterranean megacity emissions on air quality
}

\author{
U. Im and M. Kanakidou \\ Environmental Chemical Processes Laboratory (ECPL), Department of Chemistry, University of Crete, P.O. Box 2208, \\ 71003 Heraklion, Greece
}

Correspondence to: M. Kanakidou (mariak@ chemistry.uoc.gr)

Received: 30 July 2011 - Published in Atmos. Chem. Phys. Discuss.: 27 September 2011

Revised: 23 June 2012 - Accepted: 2 July 2012 - Published: 23 July 2012

\begin{abstract}
Megacities are large urban agglomerations with intensive anthropogenic emissions that have significant impacts on local and regional air quality. In the present mesoscale modeling study, the impacts of anthropogenic emissions from the Greater Istanbul Area (GIA) and the Greater Athens Area (GAA) on the air quality in GIA, GAA and the entire East Mediterranean are quantified for typical wintertime (December 2008) and summertime (July 2008) conditions. They are compared to those of the regional anthropogenic and biogenic emissions that are also calculated. Finally, the efficiency of potential country-based emissions mitigation in improving air quality is investigated.

The results show that relative contributions from both cities to surface ozone $\left(\mathrm{O}_{3}\right)$ and aerosol levels in the cities' extended areas are generally higher in winter than in summer. Anthropogenic emissions from GIA depress surface $\mathrm{O}_{3}$ in the GIA by $\sim 60 \%$ in winter and $\sim 20 \%$ in summer while those from GAA reduce the surface $\mathrm{O}_{3}$ in the GAA by $30 \%$ in winter and by $8 \%$ in summer. GIA and GAA anthropogenic emissions contribute to the fine particulate matter $\left(\mathrm{PM}_{2.5}\right)$ levels inside the cities themselves by up to $75 \%$ in winter and by $50 \%$ (GIA) and $~ 40 \%$ (GAA), in summer. GIA anthropogenic emissions have larger impacts on the domain-mean surface $\mathrm{O}_{3}$ (up to $1 \%$ ) and $\mathrm{PM}_{2.5}(4 \%)$ levels compared to GAA anthropogenic emissions $(<1 \%$ for $\mathrm{O}_{3}$ and $\leq 2 \%$ for $\mathrm{PM}_{2.5}$ ) in both seasons. Impacts of regional anthropogenic emissions on the domain-mean surface pollutant levels (up to $17 \%$ for summertime $\mathrm{O}_{3}$ and $52 \%$ for wintertime fine particulate matter, $\mathrm{PM}_{2.5}$ ) are much higher than those from Istanbul and Athens together $\left(\sim 1 \%\right.$ for $\mathrm{O}_{3}$ and $\sim 6 \%$ for $\mathrm{PM}_{2.5}$, respectively). Regional biogenic emissions are found to limit the production of secondary inorganic aerosol species in summer up to $13 \%$ (non-sea-salt sulfate
\end{abstract}

(nss- $\mathrm{SO}_{4}^{2-}$ ) in rural Athens) due to their impact on oxidant levels while they have negligible impact in winter.

Finally, the responses to country-based anthropogenic emission mitigation scenarios inside the studied region show increases in $\mathrm{O}_{3}$ mixing ratios in the urban areas of GIA and GAA, higher in winter $(\sim 13 \%$ for GIA and $2 \%$ for GAA) than in summer ( $\sim 7 \%$ for GIA and $<1 \%$ for GAA). On the opposite $\mathrm{PM}_{2.5}$ concentrations decrease by up to $30 \%$ in GIA and by $20 \%$ in GAA with the highest improvements computed for winter. The emission reduction strategy also leads to domain-wide decreases in most primary pollutants like carbon monoxide $(\mathrm{CO})$ or nitrogen oxides $\left(\mathrm{NO}_{\mathrm{x}}\right)$ for both seasons. The results show the importance of long range transport of pollutants for the air quality in the East Mediterranean. Thus, improvements of air quality in the East Mediterranean require coordinated efforts inside the region and beyond.

\section{Introduction}

More than half of the world's population is now living in urban regions (UNFPA, 2007) that show high demands of energy, transportation, industry and other facilities in their extended areas. Large urban agglomerations with more than 10 million inhabitants are characterized as megacities and represent concentrated sources of anthropogenic emissions (Lawrence et al., 2007). Their impacts on the surrounding environment and the regional and global air quality have gained significant attention in the last decades. Simulations of the export of air pollution to downwind locations via long-range transport (LRT) have shown different transport patterns depending on the megacity location: in the tropics export is occurring mostly via the free troposphere, whereas at mid 
and high latitudes it occurs within the lowest troposphere (Lawrence et al., 2007). Butler and Lawrence (2009) simulated small impacts of megacities on the oxidizing capacity of the atmosphere and larger on reactive nitrogen species on global scale. Butler et al. (2008) reported large differences in the contributions of various sectors to the total emissions at each megacity.

In addition to global studies of megacities' impacts on regional and global atmosphere, regional studies have focused on different megacities around the world (e.g. Gaffney et al. (1999), Tie et al. (2009), Li et al. (2011) and Shrivastava et al. (2011) for Mexico City; Hodnebrog et al. (2011) for European megacities and Cairo; Lin et al. (2010) for Beijing and Pearl River extended areas). These investigations clearly showed the importance of megacities as pollution sources for the surrounding areas; their contribution to regional scale ozone $\left(\mathrm{O}_{3}\right)$ and secondary aerosols during LRT and to peroxyacetyl nitrate (PAN) produced in the megacities extended areas and downwind (Gaffney et al., 1999; Molina et al., 2010). Large amounts of carbon monoxide (CO) are transported from urban centers to the downwind areas and contribute significantly to the hydroxyl $(\mathrm{OH})$ reactivity in the city and along the outflow (Tie et al., 2009: MIRAGE-Mex project (Megacities Impact on Regional and Global Environments- Mexico City Case Study)). Fires and local anthropogenic pollution induced by stagnant meteorological conditions have been identified by Konovalov et al. (2011) study with the CHIMERE mesoscale model, as the main reason of high $\mathrm{CO}$ (up to $10 \mathrm{mg} \mathrm{m}^{-3}$ ) and $\mathrm{PM}_{10}$ (particles, PM, with diameter smaller than $10 \mu \mathrm{m}$ ) (up to $700 \mathrm{\mu g} \mathrm{m}^{-3}$ ) concentrations in Moscow megacity during the 2010 Russian wildfires. The extensive field campaign MILAGRO (Megacity Initiative: Local and Global Research Observations) showed that in the urban areas particulate matter (PM) levels are double than in the rural areas, leading to significant human exposure (Molina et al., 2010).

Lin et al. (2010) identified significant differences between regional and global models in simulating the pollution inflow and outflow, particularly due to the vertical mixing of trace gases that transports pollution to the free-troposphere and from there to distant locations. In the frame of the CityZen project (Megacity-Zoom for the Environment; https: //wiki.met.no/cityzen/start), Hodnebrog et al. (2011) investigated the impact of model and associated emission resolutions for the megacities of London, Ruhr area and Cairo on large scale ozone levels, using the WRF-CHEM model and suggested that the fine-scale impacts are more likely to be resolved with high resolution mesoscale simulations. Royer et al. (2011) by comparing ground-based and lidar observations of $\mathrm{PM}_{10}$ in the Paris area with two different chemistry transport models results in the frame of MEGAPOLI (Megacities: Emissions, Urban, Regional and Global Atmospheric Pollution and Climate Effects, and Integrated Tools for Assessment and Mitigation; http://megapoli.dmi.dk/) summer campaign, demonstrated the difficulties to accurately simulate background conditions, urban plume location and dispersion and chemistry during transport.

Air pollution is an important environmental problem in the East Mediterranean where high $\mathrm{O}_{3}$ and PM levels are observed that often exceed the limits. These elevated levels result from transported pollution mixed with anthropogenic and natural emissions in the region under warm and sunny conditions that affect the region most of the year and enhance photochemical production of secondary pollutants such as $\mathrm{O}_{3}$ and secondary aerosols (Kanakidou et al., 2011). East Mediterranean is sensitive to climate change and expected to be exposed to higher levels of pollutants in the future (Im et al., 2011, 2012). The region hosts important megacities, such as Istanbul, and large urban agglomerations, such as Athens, that significantly impact on the regional air quality. Rappengluck et al. (2003), based on PAN observations at two sites on the island of Crete in the frame of the PAURII campaign and air mass back-trajectory analyses, showed that Athens and Istanbul urban plumes affect remote sites in the East Mediterranean. Koçak et al. (2011) based on observations of $\mathrm{PM}_{10}$ chemical composition from Istanbul and on forward air mass trajectory analysis showed that Istanbul emissions influence western Black Sea and East Europe during winter and Aegean and Levantine Sea during summer. Kanakidou et al. (2011) illustrated the main transport pathways of air masses from Istanbul, Athens and Cairo based on forward air mass trajectory analyses for a $30-y r$ period using reanalysis data from NCEP/NCAR. However, dedicated modeling studies on the quantitative evaluation of the impacts of the emissions from the Istanbul and Athens extended areas on the air quality in the East Mediterranean are missing. Recent developments of emission inventories for Athens (Markakis et al., 2010a, b) and Istanbul (Markakis et al., 2012) provide a solid base for the regional scale modeling of air quality in the area.

A limited number of mesoscale model investigations of air quality in the East Mediterranean elaborate the regional impact of specific emission sectors (i.e. shipping; Poupkou et al., 2008) or of total anthropogenic emission reduction scenarios on urban air quality (Im et al., 2010). Im et al. (2010) showed that under favorable meteorological conditions with low mixing heights and limited precipitation, wintertime exceedences in Istanbul can be attributed by more than $90 \%$ to local anthropogenic sources. A European-wide intercomparison study of models with different spatial resolutions, ranging from 5 to $50 \mathrm{~km}$, CityDelta, covered partly the East Mediterranean (Thunis et al., 2007) and evaluated that nitrogen oxides $\left(\mathrm{NO}_{\mathrm{x}}\right)$ control measures lead to increases in $\mathrm{O}_{3}$ levels in city centers. It also showed differences in the simulations of air flow in the urban agglomerations, emission distribution and $\mathrm{NO}_{\mathrm{x}}$ conversion to nitric acid due to the models spatial resolution. Thus, the calculated impacts of regional and local emission-reduction scenarios can vary among models. 
Recently, Im et al. $(2011,2012)$ mesoscale modeling studies have investigated the response of gaseous and particulate air pollutants to increases in air temperature during summertime, susceptible to occur during climate warming. For increasing air temperature, they found $9 \pm 3 \% \mathrm{~K}^{-1}$ increase in regional biogenic emissions and $0.9 \pm 0.1 \% \mathrm{~K}^{-1}$ increase in surface regional $\mathrm{O}_{3}$. Very weak changes in the surface regional $\mathrm{PM}_{2.5}$ levels have been simulated because the increases in particulate organic carbon (OC) are counterbalanced by the decreases in sulfate $\left(\mathrm{SO}_{4}^{2-}\right)$ levels on regional scale. Im et al. (2011) also showed that Istanbul and Athens emissions suppress $\mathrm{O}_{3}$ in the cities while they contribute to formation of $\mathrm{O}_{3}$ and other secondary species at downwind locations.

The present study builds upon these earlier works. By the means of additional mesoscale simulations, the impacts of the anthropogenic emissions from the region (East Mediterranean), and from the Istanbul megacity and from Athens extended area on the local and regional air quality are separately quantified for both summer and winter conditions. Potential gains or losses for air quality by concentrating the anthropogenic emissions in the hot spot areas in the region are also investigated. The contribution of the regional biogenic emissions is evaluated for comparison purposes. The study aims to (1) quantify the present-day contribution of these emissions to the air quality in the urban areas themselves and in the surrounding locations in the East Mediterranean as well as (2) to evaluate the potential impact of a country-based mitigation of anthropogenic emissions on the air quality in the region.

\section{Materials and methods}

The air quality modeling system used for this study consists of the Weather Research and Forecasting model (WRFARW v3.1.1; Skamarock and Klemp, 2008) coupled with the US EPA Community Multiscale Air Quality (CMAQ) model, version 4.7 (Foley et al., 2010). The Model of Emissions of Gases and Aerosols from Nature (MEGAN; Guenther et al., 2006) is used for the calculation of biogenic emissions and the global Transport Model v.4 (TM4-ECPL; Myriokefalitakis et al., 2011 and references therein) provides the monthly chemical initial and boundary conditions on a $3^{\circ}$ longitude $\times 2^{\circ}$ latitude spatial resolution on 34 vertical layers. The WRF-CMAQ domain (Fig. 1) extends over the East Mediterranean (from $31.89^{\circ} \mathrm{N}, 17.34^{\circ} \mathrm{E}$ to $43.69^{\circ} \mathrm{N}$, $\left.34.46^{\circ} \mathrm{E}\right)$ on a $30 \times 30 \mathrm{~km}$ horizontal resolution and on 23 vertical layers. Several studies have shown the sensitivity of model results and performance to grid resolution (Thunis et al., 2001; Jimenez et al., 2005; Queen and Zhang, 2008). They indicate that coarse resolutions such as used in the present study may not capture the small scale features in the cities and particularly the local impacts evaluation may be highly uncertain. Having this limitation in mind, the present

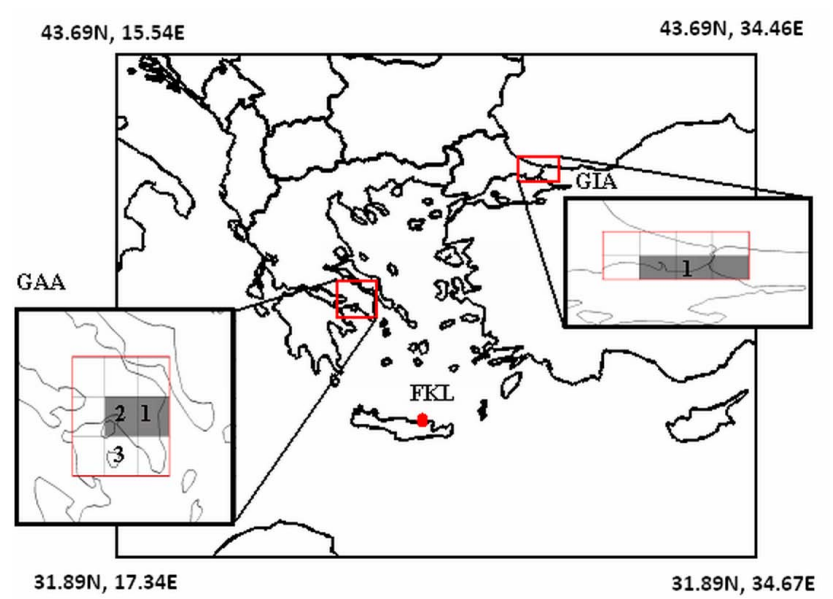

Fig. 1. Model domain, in windows the red frames indicate the Athens (GAA) and Istanbul (GIA) extended areas. The urban areas are shown in grey. In GAA, grid boxes 1,2 and 3 show the locations of GAA1, GAA2 and GAA3 groups of stations, respectively. In GIA, all stations are located in grid box 1 .

study aims to provide information on the impact of the emissions from the extended areas of the studied cities to the East Mediterranean.

The WRF model uses the WRF Single Moment 6class microphysics scheme (Hong and Lim, 2006), the RRTM (rapid radiative transfer model) longwave radiation scheme (Mlawer et al., 1997), the Dudhia shortwave radiation scheme (Dudhia, 1989), the NOAH land surface model (Chen and Dudhia, 2001), the Yonsei University Planetary Boundary Layer scheme (Hong et al., 2004) and the Kain-Fritsch cumulus parameterization scheme (Kain, 2004). The Yamartino scheme for advection (Yamartino, 1993) and asymmetric convective model (ACM2) scheme (Pleim, 2007) for vertical diffusion have been used in the CMAQ model. Nudging has been applied for temperature, wind and moisture parameters towards the NCEP reanalysis in WRF model for all model grids. The nudging coefficients are set to $0.0003 \mathrm{~s}^{-1}$ for each variable and forcing every 6 $\mathrm{h}$ has been applied. The Carbon Bond-V (CB05) gas-phase mechanism (Yardwood et al., 2005), the AERO5 aerosols module and aqueous cloud chemistry (Foley et al., 2010) have been employed in the CMAQ model. CMAQ model uses an aerosol component that considers a modal representation of aerosols. CMAQ calculates the aerosol species in Aitken, accumulation and coarse modes. It uses the ISORROPIA v1.7 thermodynamic equilibrium model (Nenes et al., 1998) that accounts for the major ions but not for the crustal species of calcium, magnesium and potassium. The aerosol module (AERO5) accounts for heterogeneous $\mathrm{N}_{2} \mathrm{O}_{5}$ hydrolysis and SOA formation (Foley et al., 2010). AERO5 also simulates sulfuric acid condensation on coarse mode and semi-volatile inorganic species (ammonia, nitric acid and 
hydrochloric acid) condensation on/evaporation from coarse mode. In this model configuration, secondary organic aerosol (SOA) production is initiated by gas-phase oxidation of aromatics, monoterpenes, sesquiterpenes and isoprene (intermediate volatility organics contribution is neglected) and aqueous-phase chemistry of carbonyls. CMAQ assumes no volatility of primary organic aerosol and treats all SOA species as semi-volatile. More details are provided in Carlton et al. (2010).

\subsection{Anthropogenic emissions}

The anthropogenic emissions for the model domain are compiled by merging emissions from Greece on $10 \mathrm{~km}$, Athens on $2 \mathrm{~km}$ (Markakis et al., 2010a, b) and from Istanbul on $2 \mathrm{~km}$ resolution (Markakis et al., 2012) into the emission inventory of the French National Institute of Industrial Environment and Risks (INERIS: https://wiki.met.no/ cityzen/page2/emissions), which is a re-gridded product of the $50 \mathrm{~km} \times 50 \mathrm{~km}$ European Monitoring and Evaluation Programme (EMEP) inventory (http://www.ceip.at/). The nonmethane volatile organic compound (NMVOC) emissions are speciated into 23 species using mean profiles from the EDGAR global inventory (Olivier et al., 2001) and the PM emissions are speciated into organic (OC) and elemental (EC) carbon, sulfates, nitrates and other species based on CARB (2007) profiles. The NMVOC emissions are then converted to CB05 species using the factors provided by Yardwood et al. (2005). The vertical distribution of emissions is calculated based on the Selected Nomenclature for Air Pollution (SNAP) codes provided by Simpson et al. (2003).

The anthropogenic and biogenic emissions from the Greater Istanbul Area (GIA), the Greater Athens Area (GAA) and the entire model domain (areas shown in Fig. 1) integrated over the winter (December 2008) and summer (July 2008) simulation periods are presented in Table 1. GAA has larger NMVOC and CO emissions compared to GIA. On the opposite, GIA has 3 to 4 times higher $\mathrm{NO}_{\mathrm{x}}$ emissions, 2 times higher $\mathrm{SO}_{2}$ emissions and $\sim 2$ times higher $\mathrm{PM}_{10}$ and $\mathrm{PM}_{2.5}$ emissions than GAA. Table 1 also shows that biogenic NMVOCs are $\sim 30$ times higher in summer than in winter. However, even during summer, the anthropogenic NMVOC emissions in GIA and GAA are by a factor of 2 and 3 , respectively, larger than the biogenic NMVOCs. The molar $\mathrm{NMVOC} / \mathrm{NO}_{\mathrm{x}}$ ratios in the emissions (Table 1) also suggest a larger potential of $\mathrm{O}_{3}$ production over GAA compared to GIA in both seasons. Furthermore, according to Table 1, GIA and GAA emissions can contribute up to more than $20 \%$ of the total regional anthropogenic emissions, depending on the pollutant.

The differences in the anthropogenic emissions also integrate the differences in the sectoral distributions of these emissions. Table S1 in the Supplement shows the contribution of major sectors (in \%) to the total anthropogenic emissions of the major primary air pollutants and how this changes between winter and summer. These changes are marked by the contribution of heating during winter. In both seasons, on-road traffic is a major source of air pollutants, particularly for $\mathrm{CO}$ and $\mathrm{NO}_{\mathrm{x}}$. Industry (including energy) is important for sulfur dioxide $\left(\mathrm{SO}_{2}\right)$ and $\mathrm{PM}$. Solvent use and traffic are the major contributors to NMVOC emissions. Table $\mathrm{S} 1$ also shows the importance of maritime emissions, particularly in GAA.

\subsection{Scenarios}

The impact of regional biogenic emissions and anthropogenic emissions from GIA and GAA, individually and together, and the whole region on the air quality of the region during winter and summer has been investigated by a set of six simulations for each period. Brute force analysis has been applied in order to zero-out the emissions by perturbing the emission files. The impact of mitigating the anthropogenic emissions on a country-based approach has been evaluated by an additional simulation for each period.

All simulations have been conducted for two 42-day periods; from 20 November 2008 to 31 December 2008 representing winter and from 20 June to 31 July 2008 representing summer. The first 11 days in both simulation periods have been considered as spin-up period and are not evaluated in the analyses. Thus, initial conditions of pollutants are not critical for the results. Tests have shown that, indeed, a $50 \%$ perturbation of the initial conditions has almost no effect $(<0.004 \%)$ on the results.

The summer period is dominated by northerlies, the socalled "Etesian" that are characteristic summertime circulation patterns in the studied area over the East Mediterranean whereas the winter simulation period is characterized by a higher frequency of southerly and western winds (Kanakidou et al., 2011). These transport patterns affect also the studied sites of Istanbul (Im et al., 2008), Athens (Kallos et al., 2007) and Finokalia (Gerasopoulos et al., 2005). Compared to winter, the summer period experiences stronger winds due to the existence of Etesian winds in the region leading to transport of pollutants to longer distances (Im et al., 2011). The studied periods have been also selected based on the availability of observations of gaseous and aerosol chemical composition for the evaluation of the model performance.

The following scenarios have been investigated for winter and summer 2008, using initial and boundary chemical conditions specific for the month of the simulation but identical for all investigated scenarios, thus, implicitly assuming the same air quality conditions outside the study areas for all scenarios:

1. Base case scenario (Base): the base case simulation uses anthropogenic and natural emissions as described in detail in Sect. 2.1.

2. Scenario Boundaries: as base but the monthly mean boundary conditions are increased by $50 \%$ for all 
Table 1. Base case and mitigated anthropogenic (including shipping) and biogenic emissions (including emissions from soils, in tons) of Greater Istanbul (GIA) and Greater Athens (GAA) areas integrated over the simulation periods of winter (December 2008) and summer (July 2008). OC and EC emissions are emitted in the fine fraction in the CMAQ model. $\mathrm{NMVOC} / \mathrm{NO}_{\mathrm{x}}$ and $\mathrm{CO} / \mathrm{NO}_{\mathrm{x}}$ are molar ratios. Areas corresponding to land surfaces in the model grid boxes shown in Fig. 1 (inner frames) are GIA: $5286 \mathrm{~km}^{2}, \mathrm{GAA} 5142 \mathrm{~km}{ }^{2}$ and Domain: $843220 \mathrm{~km}^{2}$.

\begin{tabular}{|c|c|c|c|c|c|c|c|c|c|c|}
\hline \multirow[t]{2}{*}{ Pollutants } & \multirow[t]{2}{*}{ Season } & \multicolumn{3}{|c|}{ Biogenic } & \multicolumn{3}{|c|}{ Base Anthropogenic } & \multicolumn{3}{|c|}{ Mitigated Anthropogenic } \\
\hline & & GIA & GAA & Domain & GIA & GAA & Domain & GIA & GAA & Domain \\
\hline \multirow{2}{*}{$\mathrm{CO}$ (tons) } & Winter & $<1$ & $<1$ & $<1$ & 36160 & 41253 & 590010 & 24824 & 38543 & 399410 \\
\hline & Summer & $<1$ & $<1$ & $<1$ & 31467 & 43017 & 362010 & 21768 & 40369 & 283700 \\
\hline \multirow{2}{*}{$\mathrm{NO}_{\mathrm{x}}$ (tons) } & Winter & 4 & 5 & 614 & 22505 & 6531 & 233676 & 18816 & 6255 & 213796 \\
\hline & Summer & 33 & 45 & 6579 & 22025 & 7268 & 206891 & 18533 & 6984 & 188451 \\
\hline \multirow{2}{*}{ NMVOC (tons) } & Winter & 134 & 145 & 16866 & 8432 & 10113 & 99184 & 6496 & 8789 & 83514 \\
\hline & Summer & 3998 & 4017 & 503820 & 8114 & 13328 & 81710 & 6305 & 11642 & 69100 \\
\hline \multirow{2}{*}{$\mathrm{SO}_{2}$ (tons) } & Winter & & & & 16854 & 9511 & 334630 & 16619 & 9509 & 330450 \\
\hline & Summer & & & & 8912 & 3033 & 235590 & 8835 & 3039 & 233900 \\
\hline \multirow{2}{*}{$\mathrm{NH}_{3}$ (tons) } & Winter & & & & 234 & 218 & 3515 & 234 & 218 & 3515 \\
\hline & Summer & & & & 231 & 212 & 26105 & 233 & 212 & 26105 \\
\hline \multirow{2}{*}{ OC (tons) } & Winter & & & & 751 & 621 & 9500 & 407 & 350 & 6827 \\
\hline & Summer & & & & 785 & 94 & 9426 & 424 & 53 & 6652 \\
\hline \multirow{2}{*}{ EC (tons) } & Winter & & & & 548 & 128 & 7175 & 302 & 70 & 4406 \\
\hline & Summer & & & & 416 & 163 & 5468 & 226 & 89 & 3357 \\
\hline \multirow{2}{*}{$\mathrm{PM}_{10}$ (tons) } & Winter & & & & 6575 & 3028 & 72094 & 5260 & 2327 & 58668 \\
\hline & Summer & & & & 5092 & 2204 & 52981 & 4009 & 1868 & 42910 \\
\hline \multirow{2}{*}{$\mathrm{PM}_{2.5}$ (tons) } & Winter & & & & 4486 & 2070 & 54039 & 3170 & 1589 & 40922 \\
\hline & Summer & & & & 3494 & 1502 & 39588 & 2398 & 1273 & 29503 \\
\hline \multirow{2}{*}{$\mathrm{NMVOC} / \mathrm{NO}_{\mathrm{x}}$} & Winter & 23.4 & 20.1 & 18.6 & 0.4 & 1.8 & 0.5 & 0.4 & 1.6 & 0.4 \\
\hline & Summer & 64.6 & 47.8 & 42.4 & 0.4 & 2.1 & 0.5 & 0.4 & 1.9 & 0.4 \\
\hline \multirow{2}{*}{$\mathrm{CO} / \mathrm{NO}_{\mathrm{X}}$} & Winter & $<0.1$ & $<0.1$ & $<0.1$ & 1.8 & 7 & 2.4 & 1.5 & 6.9 & 2.1 \\
\hline & Summer & $<0.1$ & $<0.1$ & $<0.1$ & 1.6 & 6.6 & 1.9 & 1.3 & 6.4 & 1.7 \\
\hline
\end{tabular}

pollutants to test sensitivity of the model results to these conditions.

3. Scenario NoBiog: as Base but masking all biogenic emissions in the model domain.

4. Scenario NoAnth: as Base but masking all anthropogenic emissions in the model domain.

5. Scenario NoIst: as Base but masking all anthropogenic emissions from GIA.

6. Scenario NoAth: as Base but masking all anthropogenic emissions from GAA.

7. Scenario NoIstAth: as Base but masking all anthropogenic emissions from both GIA and GAA.

8. Scenario Mitig: this investigates the impact of emission mitigation following a country-based scenario developed in the frame of the CityZen project. It is based on the energy projections developed within the Global Energy Assessment (GEA) by using the IIASA MESSAGE (Model for Energy Supply Strategy Alternatives and their Global Environmental Impacts) model (Messner and Struberger, 1995). Within the CityZen project, IIASA provided ratios of anthropogenic emissions in LowGWP climate-friendly scenario for the year 2030 to those for present day. LowGWP mitigates the impacts of several pollutants emitted from anthropogenic sources on climate, public health and the wider environment. For this purpose, nearly 2000 measures that are covered by the GAINS database have been evaluated considering different degrees of reductions of specific pollutant species (e.g. $\mathrm{CH}_{4}, \mathrm{CO}, \mathrm{EC}, \mathrm{OC}, \mathrm{SO}_{2}, \mathrm{NO}_{\mathrm{x}}$, VOC and $\mathrm{CO}_{2}$ ). The country-based ratios used in the present study for the countries that are within the model domain are provided in Table S2 in the Supplement. These ratios are multiplied with the base case anthropogenic emissions for each country and pollutant. For 
primary aerosol components, factors are provided for $\mathrm{PM}_{2.5}$, OC and EC. The $\mathrm{PM}_{2.5}$ factors are also applied to the other primary aerosol components. The highest reductions are projected for $\mathrm{OC}$ and $\mathrm{EC}$ emissions. A projected reduction of $15-40 \%$ in $\mathrm{PM}_{2.5}$ emissions is calculated while the reductions are up to $10 \%$ for $\mathrm{SO}_{2}$, $3-30 \%$ for $\mathrm{NO}_{\mathrm{x}}, 8-23 \%$ for NMVOCs and $5-40 \%$ for CO (Table 1).

\subsection{Data and metrics for model evaluation}

The model calculated surface $\mathrm{O}_{3}, \mathrm{CO}$, nitrogen dioxide $\left(\mathrm{NO}_{2}\right), \mathrm{SO}_{2}$ and $\mathrm{PM}_{10}$ levels have been evaluated by comparisons with ground-based observations from various measurement stations in Istanbul, Athens and Finokalia, where available (Table S3 in the Supplement). Correlation coefficient $(R)$, bias, mean normalized bias (MNB), root mean square error (RMSE), index of agreement (IOA) and mean absolute gross error (MAGE) values have been calculated in order to quantify the model performance in reproducing the observations (see equations in the Supplement). Model calculated aerosol chemical compositions are also compared with available observations in Istanbul (Theodosi et al., 2010), Athens (Paraskevopoulou et al., 2012; Pateraki et al., 2012) and Finokalia (Mihalopoulos and coworkers, unpublished data). Due to sparse aerosol sampling, the mean and standard deviations are calculated for both the model results and the observations and are compared.

\section{Results}

\subsection{Model evaluation}

Table 2 presents the comparisons of simulated surface levels of $\mathrm{O}_{3}, \mathrm{NO}_{2}, \mathrm{CO}, \mathrm{SO}_{2}$ and $\mathrm{PM}_{10}$ with ground-based observations in Istanbul, Athens and Finokalia for the two studied periods. The stations that correspond to the same model grid box (Fig. 1 and Table S3 in the Supplement) are grouped together and their mean value for each pollutant is compared with the model predictions. In GIA, all available stations fall into the same grid cell while in GAA, a distinction is made between GAA1 and GAA2 stations. However, the model resolution of $30 \mathrm{~km}$ implies that several model grids are a mixture of high and low emission surfaces, thus leading to fast dilution of the primary pollutants inside these model grids. In addition, model grids that cover both land and sea are simulated with boundary layer heights that are lower than over the land and higher than over the sea. Therefore, primary pollutants are expected to be underestimated by the model (negative bias) whereas secondary pollutants like $\mathrm{O}_{3}$ are expected to show positive bias in the model compared to the observations. For pollutants having strong primary sources and chemistry, like $\mathrm{CO}$, the impact of chemical feedbacks in the $\mathrm{O}_{3} / \mathrm{OH} / \mathrm{NO}_{\mathrm{x}} / \mathrm{CO}$ chemistry (Kanakidou and Crutzen, 1999 ) is added to the grid resolution effect.
In GIA, the model is able to simulate the temporal variation of the $\mathrm{O}_{3}$ observations both in winter (Fig. S1a) and in summer (Fig. S2a). High correlations (R-values of 0.80.9 ) are calculated particularly for $\mathrm{O}_{3}$, while for the other pollutants $R$ is always higher than 0.6 indicating that the model captures the variability of the observations (Table 2). In winter, the model slightly underestimates the observations regarding $\mathrm{O}_{3}$ (MNB of $-4 \%$ ) while in summer, there is an overestimation by $13 \%$. The differences are larger (20-60\%) for other pollutants. The variability of the wintertime $\mathrm{PM}_{10}$ is successfully simulated ( $R=0.8$; Fig. $\mathrm{S} 1 \mathrm{~b})$ while in summer a lower $R$ is calculated (0.6; Fig. S2b). $\mathrm{PM}_{10}$ levels are underestimated by $52 \%$ in winter and $58 \%$ in summer. Such underestimations can be explained by the omission of natural and re-suspended dust in the present study, although this source is shown to significantly contribute to air pollution levels in GIA (Koçak et al., 2011). Overall, the comparisons of model results with observations suggest that in GIA the model performs better for the winter period.

For GAA1 weaker correlations are calculated compared to GIA. $\mathrm{O}_{3}$ (Fig. S1c) and $\mathrm{PM}_{10}$ (Fig. S1d) variabilities are satisfactorily simulated in winter $(R=0.7)$, while in summer correlations are significant but lower $(R=0.5-0.6)$. The model overestimates the $\mathrm{O}_{3}$ levels in winter by $49 \%$, while in summer this difference decreases to $4 \%$. As discussed above, these positive biases in $\mathrm{O}_{3}$ simulations can be attributed to underestimations in $\mathrm{NO}_{\mathrm{x}}$ levels (Table 2) due to the coarse resolution of the model leading to dilution of emissions from urban areas of primary pollutant like $\mathrm{NO}_{\mathrm{x}}$. On the opposite, significantly higher correlations are calculated for $\mathrm{NO}_{2}$ and $\mathrm{CO}$ in summer $(R=0.8$ and 0.6$)$ compared to winter $(0.5$ and 0.4$)$. The differences are also larger in GAA1 compared to GIA, reaching $-84 \%$ and $-80 \%$ for $\mathrm{CO}$ in winter and summer, respectively. The model poorly simulates the summer $\mathrm{O}_{3}$ in GAA2 $(R=0.1$; Fig. S2e) while model performance for other gases is comparable with GAA1. The comparisons of $\mathrm{O}_{3}$ simulations for GAA with observations are not as good as the higher resolution simulations $(10 \mathrm{~km})$ by Honoré et al. (2008) over Western and Central Europe where pollutant emissions are better constrained. These simulations seem to better reproduce $\mathrm{O}_{3}$ in high $\mathrm{NO}_{\mathrm{x}}$ urban conditions. Finally at Finokalia (FKL), a downwind location on Crete island in the East Mediterranean, the model poorly simulates the variability in surface $\mathrm{O}_{3}$ during winter $(R=0.3$, Fig. S1g), while the mean mixing ratio is only slightly overestimated (5\%). The poor performance of our model in simulating $\mathrm{O}_{3}$ variability in winter in the East Mediterranean may be due to the boundary conditions that are applied to the mesoscale model on a monthly mean basis (simulation "boundaries" discussed in Sect. 3.2). These conditions provide information on the influence of long range transport to the air quality in the region that can drive part of the day-to-day variability of pollutants. The R-value increases to 0.7 in summer (Fig. S2g) and the MNB value also increases to $22 \%$, indicating that the model captures better 
Table 2. Simulated vs. observed surface concentrations of $\mathrm{O}_{3}, \mathrm{NO}_{2}, \mathrm{CO}, \mathrm{SO}_{2}$ and $\mathrm{PM}_{10}$ over GIA, GAA and FKL in winter (December) and summer (July) 2008. Bias and RMSE are in ppbv for $\mathrm{O}_{3}, \mathrm{NO}_{2}, \mathrm{CO}$ and $\mathrm{SO}_{2}$ and in $\mu \mathrm{g} \cdot \mathrm{m}^{-3}$ for PM 10 . MNB is in percent. $R$ and IOA have no units. $N$ denotes the number of points used in the comparisons. The equations used to calculate these statistics are provided in the Supplement.

\begin{tabular}{|c|c|c|c|c|c|c|c|c|c|c|c|c|}
\hline & \multicolumn{6}{|c|}{ Winter } & \multicolumn{6}{|c|}{ Summer } \\
\hline & $N$ & $R$ & Bias & MNB & RMSE & IOA & $N$ & $R$ & Bias & MNB & RMSE & IOA \\
\hline \multicolumn{13}{|c|}{ GIA } \\
\hline $\mathrm{O}_{3}$ & 744 & 0.8 & -2 & -4 & 4 & 0.9 & 744 & 0.9 & 5 & 13 & 7 & 0.8 \\
\hline $\mathrm{NO}_{2}$ & 744 & 0.8 & -36 & -45 & 46 & 0.5 & 744 & 0.6 & 4 & 16 & 9 & 0.7 \\
\hline $\mathrm{CO}$ & 744 & 0.7 & -388 & -52 & 456 & 0.5 & 744 & 0.7 & -118 & -36 & 127 & 0.4 \\
\hline $\mathrm{SO}_{2}$ & 744 & 0.6 & 3 & 38 & 6 & 0.7 & 744 & 0.8 & -1 & -8 & 2 & 0.8 \\
\hline $\mathrm{PM}_{10}$ & 744 & 0.8 & -32 & -52 & 39 & 0.6 & 744 & 0.6 & -26 & -58 & 27 & 0.4 \\
\hline \multicolumn{13}{|c|}{ GAA1 } \\
\hline $\mathrm{O}_{3}$ & 744 & 0.7 & 8 & 49 & 9 & 0.6 & 744 & 0.5 & 2 & 4 & 5 & 0.7 \\
\hline $\mathrm{NO}_{2}$ & 744 & 0.5 & -2 & -16 & 5 & 0.7 & 744 & 0.8 & -9 & -47 & 10 & 0.6 \\
\hline $\mathrm{CO}$ & 744 & 0.4 & -1330 & -84 & 1425 & 0.4 & 744 & 0.6 & -935 & -80 & 968 & 0.3 \\
\hline $\mathrm{SO}_{2}$ & 744 & 0.2 & $<1$ & 2 & 2 & 0.4 & 744 & 0.4 & -8 & -76 & 8 & 0.3 \\
\hline $\mathrm{PM}_{10}$ & 744 & 0.7 & -29 & -60 & 33 & 0.5 & 744 & 0.6 & -23 & -57 & 25 & 0.4 \\
\hline \multicolumn{13}{|c|}{ GAA2 } \\
\hline $\mathrm{O}_{3}$ & 744 & 0.5 & -5 & $>-1$ & 15 & 0.5 & 744 & 0.1 & 12 & 24 & 13 & 0.3 \\
\hline $\mathrm{NO}_{2}$ & 744 & 0.5 & -17 & -73 & 17 & 0.3 & 744 & 0.4 & -16 & -82 & 17 & 0.4 \\
\hline $\mathrm{CO}$ & 744 & 0.2 & -555 & -69 & 677 & 0.5 & 744 & 0.4 & -157 & -48 & 178 & 0.4 \\
\hline $\mathrm{SO}_{2}$ & 744 & 0.1 & 1 & 58 & 3 & 0.3 & 744 & 0.4 & -1 & -17 & 2 & 0.5 \\
\hline $\mathrm{PM}_{10}$ & 744 & 0.6 & -21 & -64 & 24 & 0.5 & 744 & 0.4 & -14 & -52 & 15 & 0.5 \\
\hline \multicolumn{13}{|c|}{ FKL } \\
\hline $\mathrm{O}_{3}$ & 454 & 0.3 & 2 & 5 & 4 & 0.5 & 744 & 0.7 & 12 & 22 & 13 & 0.4 \\
\hline $\mathrm{PM}_{10}$ & 373 & 0.5 & -18 & -37 & 34 & 0.4 & 598 & 0.3 & -1 & -1 & 6 & 0.5 \\
\hline
\end{tabular}

the summertime $\mathrm{O}_{3}$ variability when regional photochemistry is stronger, but overestimates the $\mathrm{O}_{3}$ levels. The calculated CO levels for winter $(134 \pm 9 \mathrm{ppbv})$ are lower by $33 \%$ than earlier observations at FKL $(200 \pm 25$ ppbv for December 2004, N. Mihalopoulos and G. Kouvarakis, personal communication, 2012). The wintertime $\mathrm{SO}_{2}$ levels at FKL seem to be overestimated by the model by $\sim 80 \%$ $(0.43 \pm 0.42$ ppbv mean observations in December 1996 and 1997 by Kouvarakis et al. (2002) against $0.77 \pm 0.38 \mathrm{ppbv}$ computed here for December 2008) that also leads to an underestimation in the wintertime nss- $\mathrm{SO}_{4}^{2-}$ levels at FKL (Table 3). Better agreement is seen for the summertime simulations in terms of $\mathrm{CO}$ and $\mathrm{SO}_{2}$, since computed $\mathrm{CO}$ levels (120 \pm 8 ppbv for July 2008) underestimate by $5 \%$ the observations (128 \pm 13 ppbv in July 2005) and $\mathrm{SO}_{2}$ levels are underestimated by $18 \%$ ( $1.54 \pm 0.6 \mathrm{ppbv}$ mean observations in July 1997 and 1999 versus $1.27 \pm 0.60$ ppbv calculated for July 2008). The model moderately reproduces the variability of the surface $\mathrm{PM}_{10}$ observations at FKL in winter $(R=0.5$, Fig. S1h), underestimating by $37 \%$ the mean observed surface concentrations. In summer, the model shows only a very small underestimation $(\sim 1 \%)$, but it does not capture the observed $\mathrm{PM}_{10}$ variability ( $R=0.3$; Table 2 ; Fig. $\mathrm{S} 2 \mathrm{~h}$ ).

The model performance is further evaluated for the aerosol chemical composition (nss-SO $\mathrm{SO}_{4}^{2-}, \mathrm{NO}_{3}^{-}, \mathrm{NH}_{4}^{+}, \mathrm{Na}^{+}, \mathrm{Cl}^{-}$, $\mathrm{OC}, \mathrm{EC})$ based on the available observations in GIA, GAA and FKL in 2008 (Table 3). In GIA, the wintertime observed and simulated $\mathrm{PM}_{10}$ aerosol chemical composition levels are generally comparable, although underestimated by the model. Particularly $\mathrm{Na}^{+}$and $\mathrm{Cl}^{-}$are highly underestimated (by factors of almost 7 and 3, respectively), which can be attributed to the contribution of coastal sea-salt emissions that are not included in this study. This underestimate persists also in summer. For other aerosol components, the summertime levels agree better with the observations, particularly for nss- $\mathrm{SO}_{4}^{2-}$, OC and EC. Observed and modeled OC/ EC ratios suggest that the model captures the primary origin of $\mathrm{OC}$ in GIA. The model shows lower performance in GAA compared to GIA for all species except for nss-SO $\mathrm{S}_{4}^{2-}$. At FKL, $\mathrm{PM}_{2.5}$ and coarse mode aerosol $\left(\mathrm{PM}_{2.5-10}\right)$ measurements are available for both seasons (Mihalopoulos and co-workers, unpublished data). Summertime and wintertime simulated $\mathrm{PM}_{2.5}$ and $\mathrm{PM}_{2.5-10}$ aerosol levels are in agreement with 
Table 3. Simulated (Mod) vs. observed (Obs) aerosol species over GIA, GAA and FKL, averaged over the simulation periods of winter (December) and summer (July) 2008. Standard deviation is given in parenthesis and units are $\mu \mathrm{g} \mathrm{m}^{-3}$. The stations used in the comparisons are Bogazici University (ESC) in GIA (Theodosi et al. (2010) for December and July 2008), Penteli in GAA1 (Paraskevopoulou et al. (2012) for December 2008 and Pateraki et al. (2012) for July 2008) and Geoponiki in GAA2 (Pateraki et al. (2012) for July 2008), Aegina in GAA3 (Pateraki et al., 2012 for July 2008) and FKL (Mihalopoulos, unpublished data for July 2008 and December 2008).

\begin{tabular}{|c|c|c|c|c|c|c|c|c|}
\hline & nss-SO ${ }_{4}^{2-}$ & $\mathrm{NO}_{3}^{-}$ & $\mathrm{NH}_{4}^{+}$ & $\mathrm{Na}^{+}$ & $\mathrm{Cl}^{-}$ & $\mathrm{OC}$ & $\mathrm{EC}$ & $\mathrm{OC} / \mathrm{EC}$ \\
\hline \multicolumn{9}{|c|}{ Winter } \\
\hline \multicolumn{9}{|c|}{ GIA $\left(\mathrm{PM}_{10}\right)$} \\
\hline Obs & $3.5(1.9)$ & $2.3(1.3)$ & $0.8(0.6)$ & $4.0(1.1)$ & $1.8(0.9)$ & $4.8(1.8)$ & $3.7(2.3)$ & 1.3 \\
\hline Mod & $2.4(0.9)$ & $1.1(0.4)$ & $0.9(0.4)$ & $0.6(0.6)$ & $0.7(0.9)$ & $2.2(0.9)$ & $1.7(0.9)$ & 1.3 \\
\hline \multicolumn{9}{|c|}{ GAA1 $\left(\mathrm{PM}_{2.5}\right)$} \\
\hline Obs & $2.8(0.9)$ & $0.7(0.3)$ & $0.2(0.1)$ & $7.6(0.4)$ & $0.5(0.2)$ & $2.5(0.5)$ & $0.4(0.2)$ & 6.8 \\
\hline Mod & $1.8(0.6)$ & $0.8(0.6)$ & $0.4(0.1)$ & $0.9(0.9)$ & $1.1(1.4)$ & $1.0(0.8)$ & $0.3(0.2)$ & 3.3 \\
\hline \multicolumn{9}{|c|}{ FKL $\left(\mathrm{PM}_{2.5}\right)$} \\
\hline Obs & $1.0(0.8)$ & $0.1(<0.1)$ & $0.5(0.3)$ & $0.1(<0.1)$ & $0.1(<0.1)$ & $0.6(0.1)$ & $0.2(0.1)$ & 3 \\
\hline Mod & $0.7(0.1)$ & $<0.1(<0.1)$ & $0.1(<0.1)$ & $0.1(0.1)$ & $0.1(<0.1)$ & $0.4(0.2)$ & $0.2(0.1)$ & 2 \\
\hline \multicolumn{9}{|c|}{$\mathrm{FKL}\left(\mathrm{PM}_{2.5-10}\right)$} \\
\hline Obs & $0.8(0.4)$ & $1.3(0.6)$ & $0.1(0.1)$ & $1.4(0.4)$ & $2.3(0.7)$ & & & \\
\hline Mod & $0.1(0.1)$ & $0.9(0.5)$ & $<0.1(<0.1)$ & $1.3(0.8)$ & $2.3(0.7)$ & & & \\
\hline \multicolumn{9}{|c|}{ Summer } \\
\hline \multicolumn{9}{|c|}{ GIA $\left(\mathrm{PM}_{10}\right)$} \\
\hline Obs & $4.2(1.6)$ & $0.6(0.2)$ & $0.4(0.2)$ & $3.3(0.4)$ & $1.2(0.3)$ & $4.1(1.0)$ & $2.1(0.4)$ & 2 \\
\hline Mod & $4.3(0.6)$ & $0.4(0.1)$ & $1.4(0.2)$ & $0.1(<0.1)$ & $<0.1(<0.1)$ & $4.0(1.2)$ & $1.6(0.5)$ & 2.5 \\
\hline \multicolumn{9}{|c|}{ GAA1 $\left(\mathrm{PM}_{2.5}\right)$} \\
\hline Obs & $4.8(2.9)$ & $0.5(0.3)$ & $1.6(1.0)$ & & $1.2(0.4)$ & $3.7(0.5)$ & $0.5(0.2)$ & 7.4 \\
\hline Mod & $3.9(1.3)$ & $<0.1(<0.1)$ & $1.0(0.3)$ & $<0.1(<0.1)$ & $<0.1(<0.1)$ & $0.8(0.2)$ & $0.5(0.2)$ & 1.6 \\
\hline \multicolumn{9}{|c|}{ GAA2 $\left(\mathrm{PM}_{2.5}\right)$} \\
\hline Obs & $6.2(3.6)$ & $0.8(0.5)$ & $1.6(1.1)$ & & $0.6(0.1)$ & $4.4(1.1)$ & $1.5(0.7)$ & 2.9 \\
\hline Mod & $3.8(1.3)$ & $<0.1(<0.1)$ & $1.0(0.3)$ & $<0.1(<0.1)$ & $<0.1(<0.1)$ & $0.6(0.1)$ & $0.3(0.1)$ & 2 \\
\hline \multicolumn{9}{|c|}{ GAA3 $\left(\mathrm{PM}_{2.5}\right)$} \\
\hline Obs & $6.0(4.1)$ & $0.3(0.1)$ & $1.6(1.3)$ & & $0.6(0.1)$ & $2.7(0.5)$ & $0.5(0.1)$ & 5.4 \\
\hline Mod & $4.1(1.4)$ & $<0.1(<0.1)$ & $1.0(0.3)$ & $<0.1(<0.1)$ & $<0.1(<0.1)$ & $0.7(0.2)$ & $0.4(0.1)$ & 1.8 \\
\hline \multicolumn{9}{|c|}{ FKL $\left(\mathrm{PM}_{2.5}\right)$} \\
\hline Obs & $6.0(2.3)$ & $0.1(<0.1)$ & $2.0(0.7)$ & $0.1(<0.1)$ & $0.4(0.1)$ & $0.3(0.1)$ & $1.2(0.4)$ & 0.3 \\
\hline Mod & $4.2(0.9)$ & $0.1(<0.1)$ & $0.7(0.1)$ & $0.2(0.1)$ & $0.1(0.1)$ & $0.3(0.1)$ & $0.7(0.1)$ & 0.4 \\
\hline \multicolumn{9}{|c|}{$\mathrm{FKL}\left(\mathrm{PM}_{2.5-10}\right)$} \\
\hline Obs & $0.5(0.6)$ & $1.3(1.5)$ & $0.2(0.1)$ & $1.0(0.7)$ & $0.9(0.6)$ & & & \\
\hline Mod & $0.5(0.2)$ & $2.0(0.5)$ & $0.1(<0.1)$ & $1.6(0.9)$ & $1.6(1.4)$ & & & \\
\hline
\end{tabular}

the measurements. At FKL $\mathrm{Na}^{+}$and $\mathrm{Cl}^{-}$levels are reasonably reproduced by the model due to the dominant northerly winds that transport the open-sea generated sea-salt particles to this downwind station. Despite the limited number of available observational data on aerosol composition for the studied period, we have compared the MAGE with the standard deviation of the observations. MAGE is significantly larger than the standard deviation of the observations for the sea-salt aerosol components in both seasons as was expected due to the omission of surf-zone sea-salt emissions in 
Table 4. Surface concentrations of main gaseous and particulate pollutants and $\mathrm{NMVOC}_{\mathrm{NO}}$ and $\mathrm{CO} / \mathrm{NO}_{\mathrm{x}}$ molar ratios simulated for the base case over urban (Urb.), rural (Rur.) and the extended areas (Ext.) of GIA and GAA, at Finokalia (FKL) and the whole simulation domain (Dom), averaged over the 31-day periods in winter (December 2008) and summer (July 2008).

\begin{tabular}{|c|c|c|c|c|c|c|c|c|c|c|c|c|c|c|c|c|}
\hline & \multicolumn{8}{|c|}{ Winter } & \multicolumn{8}{|c|}{ Summer } \\
\hline & \multicolumn{3}{|c|}{ GIA } & \multicolumn{3}{|c|}{ GAA } & \multirow[t]{2}{*}{ FKL } & \multirow[t]{2}{*}{ Dom } & \multicolumn{3}{|c|}{ GIA } & \multicolumn{3}{|c|}{ GAA } & \multirow[t]{2}{*}{ FKL } & \multirow[t]{2}{*}{ Dom } \\
\hline & Urb. & Rur. & Ext. & Urb. & Rur. & Ext. & & & Urb. & Rur. & Ext. & Urb. & Rur. & Ext. & & \\
\hline $\mathrm{O}_{3}(\mathrm{ppbv})$ & 8.1 & 22.0 & 18.0 & 17.6 & 26.5 & 25.9 & 34.7 & 33.3 & 33.2 & 56.5 & 51.0 & 47.4 & 57.6 & 56.7 & 65.2 & 62.9 \\
\hline $\mathrm{NO}_{\mathrm{x}}(\mathrm{ppbv})$ & 121.6 & 30.5 & 55.9 & 32.4 & 10.2 & 13.9 & 2.1 & 2.9 & 56.6 & 5.7 & 22.0 & 23.7 & 2.7 & 10.0 & 1.3 & 2.0 \\
\hline NMVOC (ppbC) & 121.6 & 167.8 & 195.7 & 94.0 & 33.7 & 43.1 & 8.0 & 23.5 & 62.3 & 21.1 & 61.6 & 109.0 & 24.6 & 63.0 & 8.5 & 17.6 \\
\hline $\mathrm{CO}$ (ppbv) & 367.2 & 201.6 & 247.2 & 409.7 & 205.9 & 235.6 & 132.7 & 147.4 & 222.5 & 139.6 & 165.3 & 321.7 & 131.8 & 189.6 & 120.0 & 124.0 \\
\hline PAN (ppbv) & 0.3 & 0.3 & 0.3 & 0.3 & 0.3 & 0.3 & 0.3 & 0.3 & 0.3 & 0.3 & 0.3 & 0.4 & 0.3 & 0.3 & 0.2 & 0.3 \\
\hline $\mathrm{HNO}_{3}$ (ppbv) & 1.7 & 1.1 & 1.2 & 0.9 & 0.6 & 0.8 & 0.5 & 0.7 & 3.5 & 2.5 & 2.8 & 2.2 & 1.4 & 2.2 & 1.2 & 1.6 \\
\hline $\mathrm{NMVOC} / \mathrm{NO}_{\mathrm{x}}$ & 1.0 & 5.5 & 3.5 & 2.9 & 3.3 & 3.1 & 3.8 & 8.1 & 1.1 & 3.7 & 2.8 & 4.6 & 9.1 & 6.3 & 6.5 & 8.8 \\
\hline $\mathrm{CO} / \mathrm{NO}_{\mathrm{x}}$ & 3.0 & 6.6 & 4.4 & 12.6 & 20.2 & 16.9 & 64.4 & 51.4 & 3.9 & 24.5 & 7.5 & 13.6 & 48.8 & 19.0 & 91.8 & 61.2 \\
\hline $\mathrm{PM}_{2.5}\left(\mu \mathrm{g} \mathrm{m}^{-3}\right)$ & 27.5 & 9.2 & 14.4 & 19.4 & 8.5 & 9.3 & 2.4 & 2.9 & 16.2 & 6.3 & 9.5 & 13.8 & 6.7 & 9.1 & 6.8 & 6.1 \\
\hline $\mathrm{nss}-\mathrm{SO}_{4}^{2-}\left(\mu \mathrm{g} \mathrm{m}^{-3}\right)$ & 2.7 & 1.7 & 2.0 & 2.4 & 1.5 & 1.7 & 1.0 & 1.0 & 3.9 & 3.2 & 3.4 & 4.2 & 3.6 & 4.0 & 3.8 & 3.3 \\
\hline $\mathrm{NO}_{3}^{-}\left(\mu \mathrm{g} \mathrm{m}^{-3}\right)$ & 2.7 & 0.8 & 1.5 & 0.9 & 1.2 & 0.9 & 0.7 & 0.6 & 0.9 & 0.9 & 0.8 & 0.5 & 0.5 & 0.5 & 1.8 & 1.6 \\
\hline $\mathrm{OC}\left(\mu \mathrm{g} \mathrm{m}^{-3}\right)$ & 6.3 & 1.9 & 3.1 & 5.2 & 2.0 & 2.2 & 0.4 & 0.5 & 4.1 & 1.1 & 2.0 & 1.0 & 0.7 & 0.8 & 0.8 & 0.8 \\
\hline $\mathrm{EC}\left(\mu \mathrm{g} \mathrm{m}^{-3}\right)$ & 3.0 & 1.0 & 1.5 & 0.9 & 0.4 & 0.5 & 0.2 & 0.2 & 1.6 & 0.4 & 0.8 & 0.8 & 0.4 & 0.5 & 0.3 & 0.4 \\
\hline
\end{tabular}

the model (Im et al., 2012). Significant negative biases are also computed for carbonaceous aerosols in the urban areas, pointing to the emission inventories as a potential source of uncertainties. Observed and modeled $\mathrm{OC} / \mathrm{EC}$ ratios in GAA and FKL also indicate that the secondary formation of OC is not sufficiently simulated. In summer, the model successfully simulates the OC levels and acceptably the EC levels at FKL. Both OC and EC are largely underestimated in GAA, both in winter and in summer. The EC underestimate could suggest either faster removal of EC in the model than in the atmosphere or an underestimate in the sources. The latter is a plausible explanation for the differences in summer when removal of aerosols is slow. Furthermore, the OC/EC ratio in the observations of GAA2 (Table 3 ) is higher than in the emissions (Table 1), suggesting that a significant fraction of $\mathrm{OC}$ in GAA is of secondary origin (SOA). However, the simulated OC/EC ratio is lower than the observed one, most probably due to the limitations of the model in simulating the formation of SOA as described in Sect. 2 and reported by $\mathrm{Im}$ et al. (2012). Grivas et al. (2012) based on OC, EC and $\mathrm{PM}_{10}$ observations in 2003 , have indeed estimated the secondary OC contribution to OC levels in GAA to be $\sim 20 \%$ during the cold and $\sim 30 \%$ during the warm periods. They have also estimated the primary OC/EC ratios at Goudi (GAA1) to vary between 1.6 and 2.6 with nighttime higher than daytime ratios and the warm days showing higher ratios than the cold days. Compared to the emissions of GAA adopted for the present study, the above mentioned ratios are almost 2 times lower in summer and $\sim 3$ times higher in winter. These discrepancies support the urgent need for more systematical evaluations of emissions of air pollutants and aerosol chemical characterization monitoring; such work is ongoing.

The above comparisons demonstrate model deficiencies due to its relatively coarse resolution that dilutes emissions into the model grid and introduces inaccuracies in the chem- ical simulations due to the non-linear dependence of secondary pollutants $\left(\right.$ like $\left.\mathrm{O}_{3}\right)$ to primary pollutant concentrations (like $\mathrm{NO}_{\mathrm{x}}$ ). In particular coarse models fail in simulating the extent of NO-titration of $\mathrm{O}_{3}$ in the urban areas and thus also overestimate other oxidants, like $\mathrm{OH}$ radicals, there. Thus, the simulated urban area's photochemistry is faster than observed. To quantify these uncertainties systematic high resolution simulations are required that are out of the scope of the present paper. The following calculated impacts on air quality have to be seen keeping in mind these model limitations.

\subsection{Air quality in the region}

The surface monthly mean mixing ratios of $\mathrm{O}_{3}$ and $\mathrm{PM}_{2.5}$ calculated for the base case are shown in Fig. 2a-b and Fig. 3a-b for December (winter) and July (summer), respectively. Table 4 further provides the surface concentrations of the major gases and aerosols as well as the NMVOC/ $\mathrm{NO}_{\mathrm{x}}$ and $\mathrm{CO} / \mathrm{NO}_{\mathrm{x}}$ molar ratios over the urban, the rural and the entire extended areas of GIA and GAA, the remote site of FKL and the whole simulation domain. All values are averaged over the month of each simulation.

The lowest $\mathrm{O}_{3}$ mixing ratios are calculated for the urban sites of GIA $(\sim 8 \mathrm{ppbv}$ and $\sim 33 \mathrm{ppbv}$ in winter and summer, respectively) and GAA $(\sim 18 \mathrm{ppbv}$ and $\sim 47 \mathrm{ppbv}$ in winter and summer, respectively). They are due to significant $\mathrm{NO}_{\mathrm{x}}$ emissions depressing $\mathrm{O}_{3}$ in both urban areas (Table 4) by reaction of $\mathrm{O}_{3}$ with $\mathrm{NO}$ to produce $\mathrm{NO}_{2}$ that further competes with NMVOC for reaction with $\mathrm{OH}$ radicals decreasing photochemical $\mathrm{O}_{3}$ build-up and producing $\mathrm{HNO}_{3}$ downwind. The large $\mathrm{O}_{3}$ differences between the urban and rural sites of about 9-14 ppbv $\mathrm{O}_{3}$ (for GAA and GIA, respectively) during winter and 11-24 ppbv $\mathrm{O}_{3}$ during summer, point out the importance of emissions hot spots for the air quality in their extended areas. The higher $\mathrm{O}_{3}$ levels in 

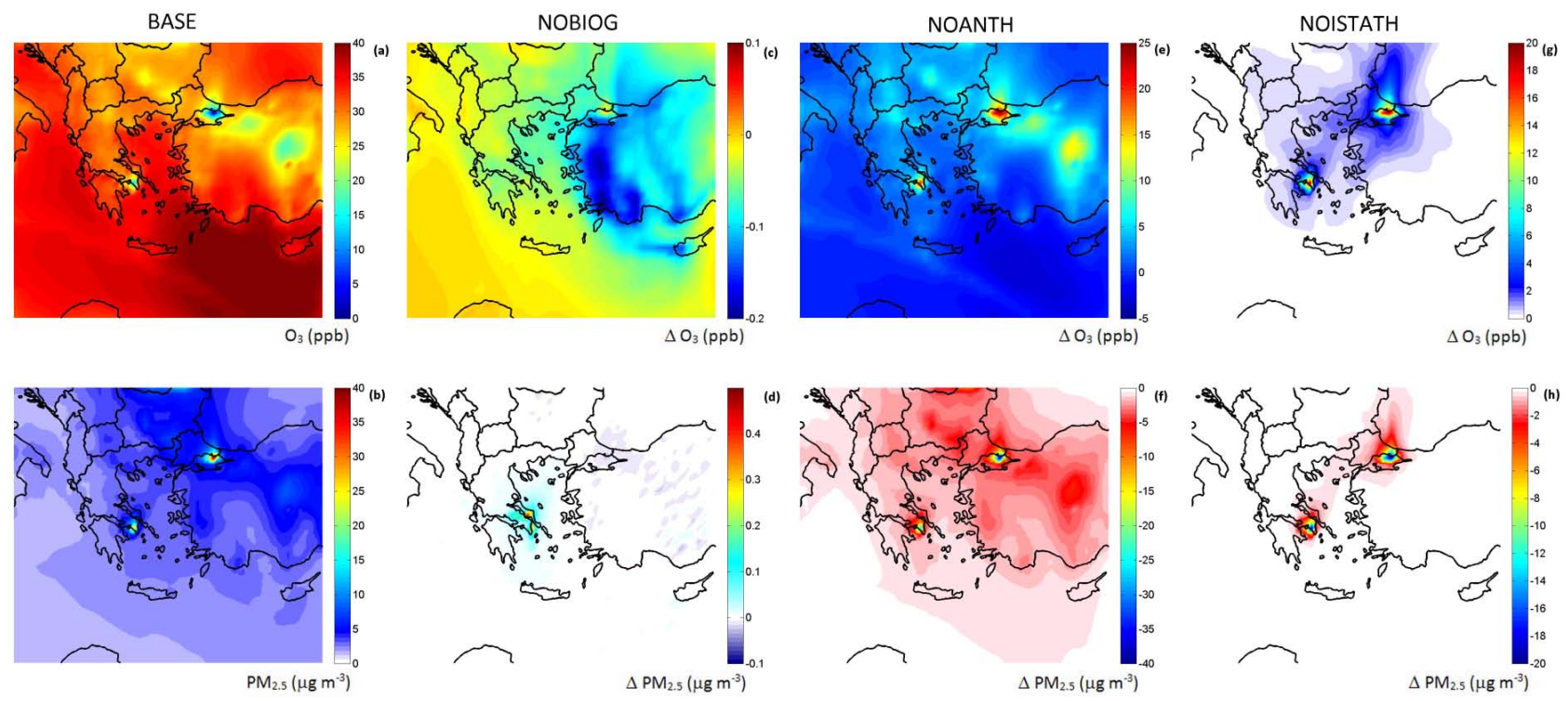

Fig. 2. Wintertime (December 2008) surface $\mathrm{O}_{3}(\mathbf{a}, \mathbf{c}, \mathbf{e}, \mathbf{g})$ and $\mathrm{PM}_{2.5}(\mathbf{b}, \mathbf{d}, \mathbf{f}, \mathbf{h})$ levels calculated from the base case scenario $(\mathrm{Base}$ : a, b) and the absolute differences of scenarios "NoBiog" $(\mathbf{c}, \mathbf{d})$, "NoAnth" $(\mathbf{e}, \mathbf{f})$ and "NoIstAth" $(\mathbf{g}, \mathbf{h})$ from the "Base", averaged for the month of the simulation. Units are ppbv for $\mathrm{O}_{3}$ and $\Delta \mathrm{O}_{3}$ and $\mu \mathrm{g} \mathrm{m}^{-3}$ for $\mathrm{PM}_{2.5}$ and $\Delta \mathrm{PM}_{2.5}$.
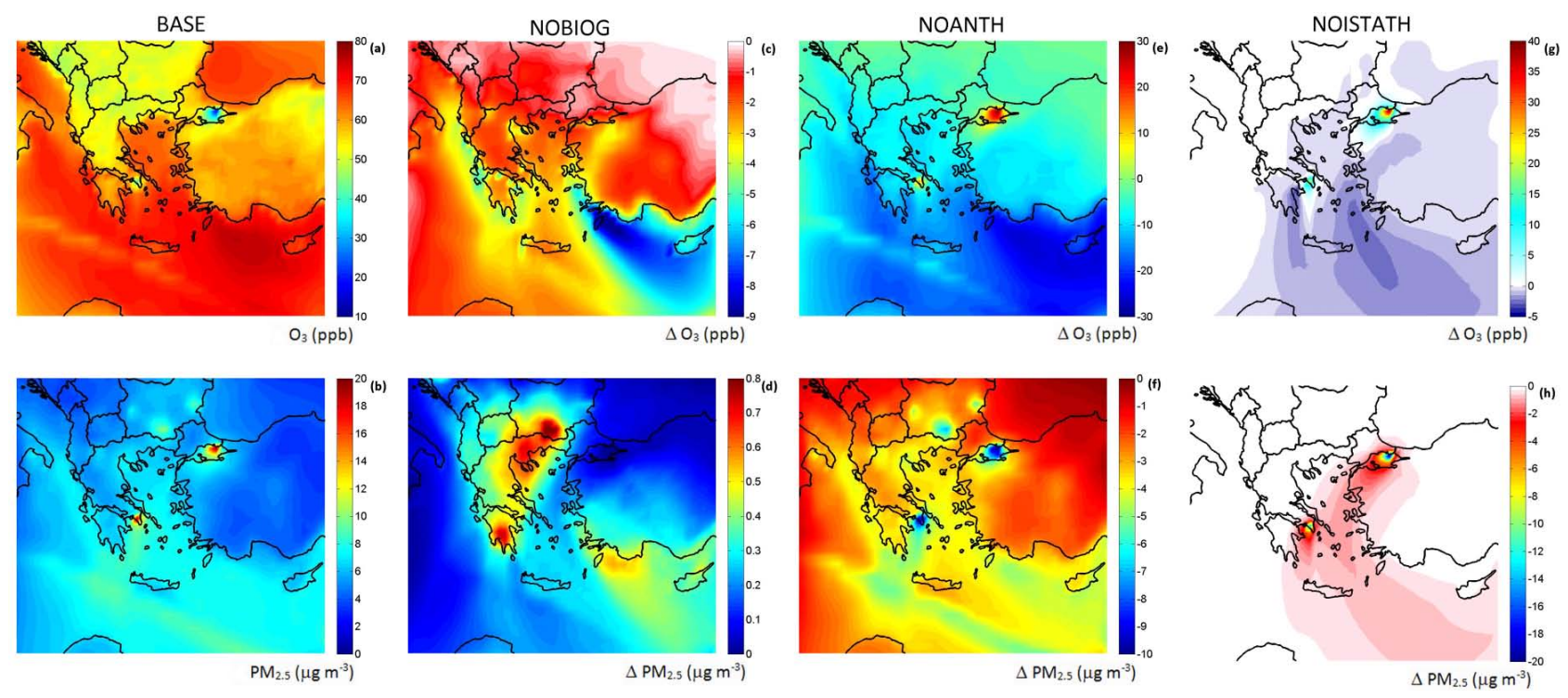

Fig. 3. Summertime (July 2008) surface $\mathrm{O}_{3}(\mathbf{a}, \mathbf{c}, \mathbf{e}, \mathbf{g})$ and $\mathrm{PM}_{2.5}(\mathbf{b}, \mathbf{d}, \mathbf{f}, \mathbf{h})$ levels calculated from the base case scenario (Base: a, b) and the absolute differences of scenarios "NoBiog" $(\mathbf{c}, \mathbf{d})$, "NoAnth" $(\mathbf{e}, \mathbf{f})$ and "NoIstAth" (g, h) from the "Base", averaged for the month of the simulation. Units are ppbv for $\mathrm{O}_{3}$ and $\Delta \mathrm{O}_{3}$ and $\mu \mathrm{g} \mathrm{m}{ }^{-3}$ for $\mathrm{PM}_{2.5}$ and $\Delta \mathrm{PM}_{2.5}$.

Athens than in Istanbul can be attributed to the elevated background of $\mathrm{O}_{3}$ and the primary pollutant emissions mixture in the GAA. The elevated background in GAA is due to long range transport and regional emissions of primary and secondary pollutants that react under the favorable climate conditions (temperature and solar radiation) in the region. The impact of transport is also supported by the $\mathrm{CO} / \mathrm{NO}_{\mathrm{x}}$ molar ratios (Table 4). This ratio increases from Istanbul to Athens and then to Finokalia showing the significant impact of local emissions in Istanbul compared to increased regional background in Athens and at Finokalia (Kanakidou et al., 2011; Parrish et al., 2009). It also shows that air masses age chemically when travelling from the north to the south, leading to lower $\mathrm{CO} / \mathrm{NO}_{\mathrm{x}}$ ratios in the most aged air masses. The difference in $\mathrm{O}_{3}$ levels in GIA and GAA also reflects differences in the NMVOC reactivity between the two cities. To further analyze these patterns the integrated NMVOC 


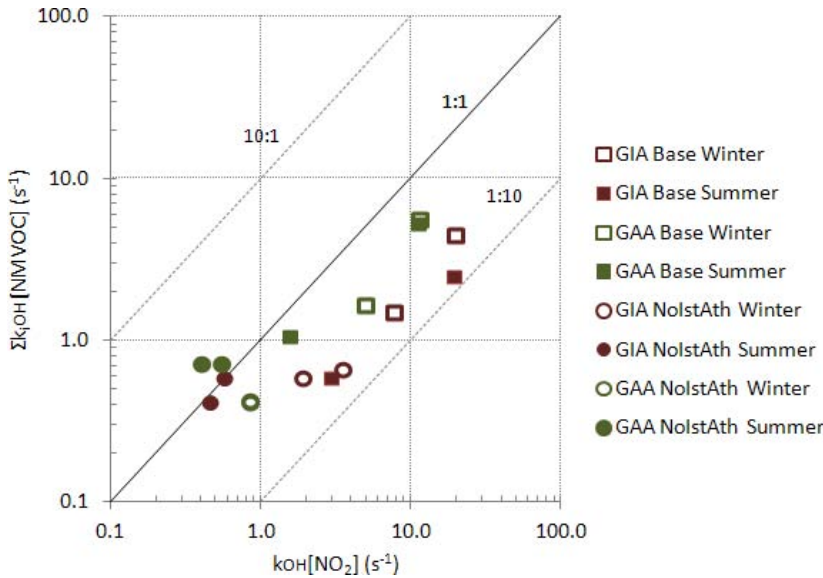

Fig. 4. Integrated NMVOC reactivity with regard to $\mathrm{OH}$ radical as a function of $\mathrm{NO}_{2}$ reactivity with regard to $\mathrm{OH}$ radical at GIA (purple) and GAA (green) for summer (July 2008; closed symboles) and winter (December 2008; open symboles) for the "Base" (squares) and the "NoIstAth" (circles) simulations. Values averaged for rural and for urban cases separately. The 10:1, 1:1 and 1:10 lines are plotted for clarity. Units are $\mathrm{s}^{-1}$.

reactivity with respect to $\mathrm{OH}\left(\sum_{i} k_{\mathrm{OH}}^{i}\left[\mathrm{NMVOC}_{i}\right]\right)$ has been computed ( $i$ denotes the various NMVOC present in the atmosphere). This has been compared to the product of the rate of $\mathrm{NO}_{2}$ reaction with $\mathrm{OH}\left(k_{\mathrm{OH}}\right)$ with the computed $\mathrm{NO}_{2}$ concentration $\left(k_{\mathrm{OH}} \cdot\left[\mathrm{NO}_{2}\right]\right)$. Figure 4 depicts the monthly mean $\left(\sum_{i} k_{\mathrm{OH}}^{i}\left[\mathrm{NMVOC}_{i}\right]\right)$ as a function of the corresponding $k_{\mathrm{OH}} \cdot\left[\mathrm{NO}_{2}\right]$ for GIA and GAA urban and rural areas for summer and winter. For the base case simulations in both cities $\mathrm{NO}_{2}$ reactivity is higher than the integrated NMVOC reactivity. GAA has a higher integrated NMVOC reactivity than GIA, while GIA experiences higher $\mathrm{NO}_{2}$ levels and $\mathrm{NO}_{2}$ reactivity than GAA in consistence with the emission patterns shown in Table 1. Precisely, in Athens rural areas the integrated NMVOC reactivity is by $10 \%$ to a factor of 2 higher compared to Istanbul rural areas in winter and summer, respectively. This translates to 2 to 4 times higher ratio of $\left(\sum_{i} k_{\mathrm{OH}}^{i}\left[\mathrm{NMVOC}_{i}\right]\right) / k_{\mathrm{OH}} \cdot\left[\mathrm{NO}_{2}\right]$ in GAA than in GIA rural areas that, combined with the high $\mathrm{NO}_{2}$ levels in Istanbul, favors $\mathrm{HNO}_{3}$ formation than $\mathrm{O}_{3}$ formation in GIA more than in GAA. Similar conclusions can be drawn when also accounting for the $\mathrm{CO}$ reactivity with respect to $\mathrm{OH}$.

The highest surface $\mathrm{O}_{3}$ mixing ratios are calculated over the Southeast Mediterranean Sea, particularly east of Crete for both seasons (Figs. 2a and 3a). Surface $\mathrm{O}_{3}$ at the Finokalia station is calculated to reach $35 \mathrm{ppbv}$ in winter and $65 \mathrm{ppbv}$ in summer that is very close to the domain mean surface $\mathrm{O}_{3}$ levels ( $33 \mathrm{ppbv}$ in winter and $63 \mathrm{ppbv}$ in summer).

Opposite to $\mathrm{O}_{3}$, the highest $\mathrm{PM}_{2.5}$ concentrations are calculated over the emission hot spot areas as depicted in
Figs. $2 \mathrm{~b}$ and $3 \mathrm{~b}$ in agreement with earlier studies (Im et al., 2012; Kanakidou et al., 2011). In GIA and GAA, wintertime $\mathrm{PM}_{2.5}$ levels $\left(28 \mu \mathrm{g} \mathrm{m}^{-3}\right.$ in GIA and $19 \mu \mathrm{g} \mathrm{m}^{-3}$ in GAA, Table 4 and Fig. 2b) are higher than the summertime levels $\left(16 \mu \mathrm{g} \mathrm{m}^{-3}\right.$ and $14 \mu \mathrm{g} \mathrm{m}^{-3}$, respectively, Fig. 3b) due to higher anthropogenic emissions in winter (Table 1) and weaker winds. In both extended areas, $\mathrm{PM}_{2.5}$ decreases by a factor of $\sim 2-3$ from the urban areas to the rural suburbs (Table 4). Significant $\mathrm{PM}_{2.5}$ levels are also computed over the Mediterranean Sea, in particular over the shipping lines in the southwest of Peloponnesus and Crete. Table 4 shows that the differences between the urban and rural sites of the GIA and GAA are most pronounced for OC (a factor of $\sim 3$ in winter and 1.5-4 times in summer) and EC (2-3 times in winter and 2-4 times in summer) levels. In GIA and GAA large fraction of OC is primary anthropogenic in winter while secondary fraction becomes more important in summer, in agreement with the observations by Theodosi et al. (2010) for Istanbul and by Grivas et al. (2012) for Athens.

The computed levels of air pollutants significantly depend on the boundary conditions. Perturbation by $50 \%$ of the boundary conditions of all pollutants for which boundary conditions are used (monthly mean levels provided by the global model) leads to more than $\sim 50 \%$ change in monthly and domain mean $\mathrm{O}_{3}$ and PAN levels (Table S4). Domain mean levels of the major gaseous pollutants change by $\sim 10$ $50 \%$ in winter and $\sim 10-45 \%$ in summer whereas those of aerosol components change by $\sim 15-30 \%$ in winter and $\sim 5-25 \%$ in summer. These results indicate the importance of the long range transport for the air quality in the region and thus the sensitivity of the model results to the boundary conditions. They should, therefore, be considered while quantifying and evaluating the impacts of emissions and mitigation.

\subsection{Impact of regional biogenic and anthropogenic emissions}

The impact of biogenic emissions on air quality due to the chemical interactions with emissions of pollutants like $\mathrm{NO}_{\mathrm{x}}$ is investigated by the simulation NoBiog, where the biogenic emissions in the whole model domain are omitted. The differences in $\mathrm{O}_{3}$ and $\mathrm{PM}_{2.5}$ from the base case simulation are depicted in Fig. 2c, $d$ for winter and in Fig. 3c, $d$ for summer (see also in Table 5 and Table S5 in the Supplement). $\mathrm{O}_{3}$ mixing ratios are reduced throughout the domain with larger differences in summer, when biogenic emissions are high (Figs. 2c and 3c). The monthly mean differences in the $\mathrm{O}_{3}$ surface mixing ratios are less than $0.1 \mathrm{ppbv}$ in winter while in summer they are 1 ppbv (2\%) in GIA, 3 ppbv (6\%) in GAA and 2 ppbv (3\%) at FKL (Table 5). 
Table 5. Differences (\%) in the mean winter (December 2008) and summer (July 2008; in parenthesis) surface concentrations of air pollutants and chemical indicators in GIA, and GAA (urban, rural suburbs and extended areas), at FKL and the whole domain due to masking of anthropogenic emissions from the GIA and/or GAA. Changes marked as $>-1$ refer to values between 0 and -1 and changes marked as $<1$ refer to positive values. Values are computed as [100 (Scenario-Base)/Base].

\begin{tabular}{|c|c|c|c|c|c|c|c|c|}
\hline \multirow[t]{2}{*}{ (a) Gases } & \multicolumn{3}{|c|}{ GIA } & \multicolumn{3}{|c|}{ GAA } & \multirow[t]{2}{*}{ FKL } & \multirow[t]{2}{*}{ Domain } \\
\hline & Urban & Rural & Extended & Urban & Rural & Extended & & \\
\hline \multicolumn{9}{|l|}{$\mathrm{O}_{3}$} \\
\hline NoIst & $238(81)$ & $32(6)$ & $61(22)$ & $1(>-1)$ & $1(>-1)$ & $1(>-1)$ & $1(-2)$ & $1(>-1)$ \\
\hline NoAth & $0(<1)$ & $0(<1)$ & $0(<1)$ & $89(28)$ & $23(1)$ & $30(8)$ & $0(-1)$ & $0(>-1)$ \\
\hline NoIstAth & $236(80)$ & $32(6)$ & $61(22)$ & $90(27)$ & $24(1)$ & $31(8)$ & $1(-2)$ & $1(-1)$ \\
\hline NoAnth & $299(68)$ & $45(-2)$ & $80(14)$ & $92(10)$ & $25(-13)$ & $31(-8)$ & $-1(-18)$ & $4(-17)$ \\
\hline NoBiog & $<-1(-3)$ & $<-1(-1)$ & $<-1(-2)$ & $<-1(-6)$ & $<-1(-4)$ & $<-1(-6)$ & $<-1(-3)$ & $<-1(-4)$ \\
\hline \multicolumn{9}{|l|}{$\mathrm{NO}_{\mathrm{x}}$} \\
\hline NoIst & $-95(-98)$ & $-89(-86)$ & $-93(-96)$ & $<-1(<1)$ & $-2(<1)$ & $-1(<1)$ & $-4(-1)$ & $-18(-9)$ \\
\hline NoAth & $0(0)$ & $0(0)$ & $0(0)$ & $-95(-96)$ & $-85(-74)$ & $-89(-92)$ & $-1(-2)$ & $-3(-3)$ \\
\hline NoIstAth & $-95(-98)$ & $-89(-86)$ & $-93(-96)$ & $-95(-96)$ & $-85(-74)$ & $-89(-92)$ & $-5(-2)$ & $-21(-12)$ \\
\hline NoAnth & $-100(-100)$ & $-100(-97)$ & $-100(-99)$ & $-100(-99)$ & $-99(-91)$ & $-99(-98)$ & $-96(-90)$ & $-94(-90)$ \\
\hline NoBiog & $0(<1)$ & $<-1(2)$ & $0(1)$ & $<-1(1)$ & $<-1(-2)$ & $<-0.1(1)$ & $<-1(-2)$ & $<-1(0)$ \\
\hline \multicolumn{9}{|l|}{$\mathrm{CO}$} \\
\hline NoIst & $-59(-44)$ & $-26(-7)$ & $-39(-23)$ & $0(>-1)$ & $-1(>-1)$ & $<-1(>-1)$ & $<-1(-1)$ & $-1(-1)$ \\
\hline NoAth & $0(>-1)$ & $0(>-1)$ & $0(>-1)$ & $-67(-64)$ & $-35(-13)$ & $-42.5(-39)$ & $<-1(-2)$ & $-1(-1)$ \\
\hline NoIstAth & $-59(-44)$ & $-25(-7)$ & $-39(-23)$ & $-67(-64)$ & $-35(-14)$ & $-43(-39)$ & $-1(-3)$ & $-1(-2)$ \\
\hline NoAnth & $-64(-46)$ & $-34(-9)$ & $-47(-25)$ & $-69(-66)$ & $-38(-17)$ & $-45(-42)$ & $-4(-7)$ & $-9(-6)$ \\
\hline NoBiog & $<-1(-1)$ & $<-1(-1)$ & $<-1(-1)$ & $<-1(-1)$ & $<-1(-3)$ & $<-1(-2)$ & $<-1(-3)$ & $<-1(-3)$ \\
\hline \multicolumn{9}{|l|}{ PAN } \\
\hline NoIst & $4(-6)$ & $3(-7)$ & $3(-8)$ & $<1(-1)$ & $<1(-1)$ & $<1(-1)$ & $0(-6)$ & $<1(-2)$ \\
\hline NoAth & $<-1(<1)$ & $<-1(<1)$ & $<-1(<1)$ & $1(-29)$ & $-1(-15)$ & $-1(-28)$ & $<-1(-4)$ & $<-1(-1)$ \\
\hline NoIstAth & $5(-6)$ & $-4(-7)$ & $-7(-8)$ & $-20(-30)$ & $-13(-16)$ & $-24(-29)$ & $-19(-10)$ & $<-1(-3)$ \\
\hline NoAnth & $-12(-44)$ & $-11(-47)$ & $-12(-47)$ & $-17(-70)$ & $-17(-62)$ & $-17(-70)$ & $-20(-72)$ & $-13(-53)$ \\
\hline NoBiog & $-2(-25)$ & $-2(-21)$ & $-2(-23)$ & $-1(-44)$ & $-1(-45)$ & $-1(-45)$ & $-1(-38)$ & $-1(-34)$ \\
\hline \multicolumn{9}{|l|}{$\mathrm{HNO}_{3}$} \\
\hline NoIst & $-51(-61)$ & $-18(-35)$ & $-30(-47)$ & $1(-4)$ & $1(-5)$ & $1(-4)$ & $-3(14)$ & $-3(-8)$ \\
\hline NoAth & $<-1(>-1)$ & $<-1(>-1)$ & $<-1(>-1)$ & $-19(-44)$ & $7(-16)$ & $-9(-41)$ & $-2(-7)$ & $-2(-2)$ \\
\hline NoIstAth & $-51(-61)$ & $-18(-35)$ & $-30(-47)$ & $-20(-47)$ & $7(-21)$ & $-9(-44)$ & $-6(-21)$ & $-5(-10)$ \\
\hline NoAnth & $-93(-83)$ & $-91(-77)$ & $-90(-77)$ & $-92(-79)$ & $-89(-65)$ & $-91(-78)$ & $-87(-79)$ & $-75(-72)$ \\
\hline NoBiog & $<1(-1)$ & $<1(1)$ & $<1(<1)$ & $<1(5)$ & $1(11)$ & $1(6)$ & $<1(7)$ & $<1(7)$ \\
\hline
\end{tabular}

For $\mathrm{PM}_{2.5}$ (Figs. $2 \mathrm{~d}$ and $3 \mathrm{~d}$ ) both positive and negative responses to the omission of biogenic emissions are computed. In particular, GIA responds differently than GAA and other locations in the model domain. To understand this behavior the changes in the chemical composition of $\mathrm{PM}_{2.5}$ have been investigated. Biogenic emissions impact on the OC concentrations (Fig. 5a, d) via changes in the secondary organic aerosol (SOA) formation, particularly in summer when these emissions maximize (Fig. 5d). Omitting these emissions (NoBiog), the monthly mean summertime OC levels decrease by $2 \%$ in GIA, $8 \%$ in GAA and $5 \%$ at FKL. On the opposite, an increase is computed for most other aerosol components and particularly nss- $\mathrm{SO}_{4}^{2-}$ in summer and there- fore, to an overall increase in domain-mean $\mathrm{PM}_{2.5}$ level by $4 \%$ (Table 5 and Fig. 5). The general underestimate of SOA by the model, discussed in Sect. 3.1, implies that the computed changes could also underestimate the BVOC impact on OC. However, our results point to the key role of biogenic NMVOCs in limiting the production of secondary inorganic species (e.g. nss- $\mathrm{SO}_{4}^{2-}$ and $\mathrm{NO}_{3}^{-}$) by reducing the oxidant levels in the region. In particular, the computed increase in the "NoBiog" case, of significance during summer, can be attributed to the increase in the domain-mean hydroxyl radical $(\mathrm{OH})$ levels by $25 \%$ in summer (Fig. 5c, f; surface computed distributions for the Base simulation are depicted in Fig. S3 in the Supplement). The impact of biogenic emissions in 
Table 5. Continued.

\begin{tabular}{|c|c|c|c|c|c|c|c|c|}
\hline \multirow[t]{2}{*}{ (b) Aerosols } & \multicolumn{3}{|c|}{ GIA } & \multicolumn{3}{|c|}{ GAA } & \multirow[t]{2}{*}{ FKL } & \multirow[t]{2}{*}{ Domain } \\
\hline & Urban & Rural & Extended & Urban & Rural & Extended & & \\
\hline \multicolumn{9}{|l|}{$\mathrm{PM}_{2.5}$} \\
\hline $\begin{array}{l}\text { NoIst } \\
\text { NoAth } \\
\text { NoIstAth } \\
\text { NoAnth } \\
\text { NoBiog }\end{array}$ & $\begin{array}{r}-85(-72) \\
<-1(>-1) \\
-85(-72) \\
-95(-80) \\
<-1(>-1)\end{array}$ & $\begin{array}{r}-60(-21) \\
<-1(>-1) \\
-60(-21) \\
-85(-44) \\
<-1(<1)\end{array}$ & $\begin{array}{r}-74(-50) \\
<-1(>-1) \\
-74(-50) \\
-91(-64) \\
<-1(<1)\end{array}$ & $\begin{array}{r}1(-1) \\
-88(-59) \\
-88(-60) \\
-94(-78) \\
<1(3)\end{array}$ & $\begin{array}{r}1(-2) \\
-72(-15) \\
-72(-17) \\
-87(-56) \\
1(7)\end{array}$ & $\begin{array}{r}1(-1) \\
-75(-37) \\
-75(-38) \\
-88(-67) \\
1(4)\end{array}$ & $\begin{array}{r}-1(-7) \\
-1(-2) \\
-3(-9) \\
-49(-46) \\
<1(4)\end{array}$ & $\begin{array}{r}-4(-4) \\
-2(-1) \\
-6(-5) \\
-52(-47) \\
<1(4)\end{array}$ \\
\hline \multicolumn{9}{|l|}{$\mathrm{nss}-\mathrm{SO}_{4}^{2-}$} \\
\hline $\begin{array}{l}\text { NoIst } \\
\text { NoAth } \\
\text { NoIstAth } \\
\text { NoAnth } \\
\text { NoBiog }\end{array}$ & $\begin{array}{r}-49(-29) \\
<-1(>-1) \\
-49(-29) \\
-77(-48) \\
0(2)\end{array}$ & $\begin{array}{r}-23(-8) \\
-1(>-1) \\
-23(-8) \\
-63(-33) \\
0(3)\end{array}$ & $\begin{array}{r}-33(-17) \\
<-1(>-1) \\
-33(-17) \\
-68(-39) \\
0(2)\end{array}$ & $\begin{array}{r}<1(-2) \\
-55(-16) \\
-55(-18) \\
-78(-56) \\
<1(10)\end{array}$ & $\begin{array}{r}<1(-2) \\
-30(-3) \\
-30(-4) \\
-66(-49) \\
<1(13)\end{array}$ & $\begin{array}{r}<1(-2) \\
-35(-11) \\
-35(-13) \\
-65(-54) \\
<1(11)\end{array}$ & $\begin{array}{r}<-1(-7) \\
-1(-1) \\
-2(-8) \\
-47(-49) \\
<1(8)\end{array}$ & $\begin{array}{r}-1(-4) \\
-1(-1) \\
-3(-4) \\
-48(-45) \\
<1(8)\end{array}$ \\
\hline \multicolumn{9}{|l|}{$\mathrm{NO}_{3}^{-}$} \\
\hline $\begin{array}{l}\text { NoIst } \\
\text { NoAth } \\
\text { NoIstAth } \\
\text { NoAnth } \\
\text { NoBiog }\end{array}$ & $\begin{array}{r}-86(-45) \\
<1(1) \\
-86(-46) \\
-95(-63) \\
<1(1) \\
\end{array}$ & $\begin{array}{r}-40(-6) \\
<-1(1) \\
-41(-6) \\
-75(-36) \\
<1(1)\end{array}$ & $\begin{array}{r}-70(-23) \\
<1(1) \\
-70(-23) \\
-88(-48) \\
<1(1)\end{array}$ & $\begin{array}{r}<1(-3) \\
-51(-23) \\
-51(27) \\
-86(-71) \\
1(6)\end{array}$ & $\begin{array}{r}1(-3) \\
-66(-19) \\
-67(-22) \\
-90(-70) \\
1(9)\end{array}$ & $\begin{array}{r}1(-3) \\
-47(-21) \\
-48(-24) \\
-85(-70) \\
1(6)\end{array}$ & $\begin{array}{r}-7(-16) \\
-1(-1) \\
-8(-18) \\
-71(-72) \\
<-1(3)\end{array}$ & $\begin{array}{r}-3(-6) \\
-1(-1) \\
-5(-8) \\
-57(-74) \\
<1(4)\end{array}$ \\
\hline \multicolumn{9}{|l|}{$\mathrm{OC}$} \\
\hline $\begin{array}{l}\text { NoIst } \\
\text { NoAth } \\
\text { NoIstAth } \\
\text { NoAnth } \\
\text { NoBiog }\end{array}$ & $\begin{array}{l}-89(-84) \\
<-1(<1) \\
-89(-84) \\
-96(-88) \\
<-1(-1)\end{array}$ & $\begin{array}{r}-72(-32) \\
<-1(1) \\
-71(-32) \\
-87(-51) \\
<-1(-2) \\
\end{array}$ & $\begin{array}{l}-81(-65) \\
<-1(<1) \\
-81(-65) \\
-92(-75) \\
<-1(-2)\end{array}$ & $\begin{array}{r}1(-1) \\
-93(-41) \\
-93(-43) \\
-96(-63) \\
<1(-6) \\
\end{array}$ & $\begin{array}{r}1(-1) \\
-80(-8) \\
-80(-11) \\
-90(-42) \\
1(-9) \\
\end{array}$ & $\begin{array}{r}1(-1) \\
-83(-22) \\
-83(-25) \\
-91(-51) \\
1(-8) \\
\end{array}$ & $\begin{array}{r}-1(-7) \\
-1(<1) \\
-2(-8) \\
-41(-48) \\
<1(-5) \\
\end{array}$ & $\begin{array}{r}-5(-4) \\
-3(<1) \\
-8(-5) \\
-46(-48) \\
<-1(-6)\end{array}$ \\
\hline \multicolumn{9}{|l|}{$\mathrm{EC}$} \\
\hline $\begin{array}{l}\text { NoIst } \\
\text { NoAth } \\
\text { NoIstAth } \\
\text { NoAnth } \\
\text { NoBiog }\end{array}$ & $\begin{array}{r}-87(-84) \\
<-1(<1) \\
-86(-84) \\
-97(-89) \\
0(<1)\end{array}$ & $\begin{array}{r}-67(-34) \\
<-1(<1) \\
-67(-34) \\
-91(-55) \\
0(<1)\end{array}$ & $\begin{array}{r}-77(-67) \\
<-1(<1) \\
-77(-67) \\
-94(-77) \\
0(<1)\end{array}$ & $\begin{array}{r}<1(-1) \\
-79(-67) \\
-79(-68) \\
-93(-81) \\
<1(<1)\end{array}$ & $\begin{array}{r}<1(-1) \\
-57(-27) \\
-57(-28) \\
-85(-57) \\
<1(<1)\end{array}$ & $\begin{array}{r}<1(-1) \\
-61(-47) \\
-61(-48) \\
-86(-69) \\
<1(<1)\end{array}$ & $\begin{array}{r}-2(-9) \\
-1(-2) \\
-2(-10) \\
-61(-52) \\
<1(<1)\end{array}$ & $\begin{array}{r}-5(-5) \\
-1(-1) \\
-6(-6) \\
-61(-48) \\
<1(<1)\end{array}$ \\
\hline
\end{tabular}

winter is negligible. The largest changes in $\mathrm{OH}$ levels are computed to occur over land where the emissions take place. Similar conclusions on the role of biogenic emissions and the $\mathrm{PM}_{2.5}$ behavior have been drawn by Im et al. (2012) for the summer of 2004. These results agree with the findings by Kiendler-Scharr et al. (2009) who observed during plant chamber experiments decreased aerosol concentrations with increasing isoprene levels, showing that the high reactivity of isoprene with $\mathrm{OH}$ leads to suppression of new particle formation. However, although the role of biogenic NMVOC in limiting oxidant levels is established, the magnitude of the decrease in $\mathrm{OH}$ under low $\mathrm{NO}_{\mathrm{x}}$ and high NMVOC conditions remains uncertain since recent observations indicate significant $\mathrm{OH}$ recycling under such conditions (Hofzumahaus et al., 2009; Taraborrelli et al., 2012).
Simulations "NoAnth" enable the evaluation of the contributions of all regional anthropogenic emissions on the domain-mean surface pollutant levels. In winter these contributions (Fig. 2e; Table 5) are $94 \%$ for $\mathrm{NO}_{\mathrm{x}}, 9 \%$ for $\mathrm{CO}$, $13 \%$ for $\mathrm{PAN}$ and $75 \%$ for $\mathrm{HNO}_{3}$. In the absence of all regional anthropogenic emissions the domain-mean $\mathrm{PM}_{2.5}$ levels also decrease to about half due to similar reductions in all major aerosol components (nss- $\mathrm{SO}_{4}^{2-}$ by $48 \%, \mathrm{NO}_{3}^{-}$by $57 \%$, OC by $46 \%$, and EC by $61 \%$ ). On the opposite, winter $\mathrm{O}_{3}$ levels increase by about $4 \%$ when regional anthropogenic emissions are masked. In summer (Fig. 2f), larger impacts are computed: Regional anthropogenic emissions contribute to the domain mean levels of $\mathrm{NO}_{\mathrm{x}}$ by $90 \%, \mathrm{CO}$ by $6 \%$, PAN by $53 \%$ and $\mathrm{HNO}_{3}$ by $72 \%$ while $\mathrm{O}_{3}$ levels are suppressed by $17 \%$. This $\mathrm{O}_{3}$ reduction is comparable with the 

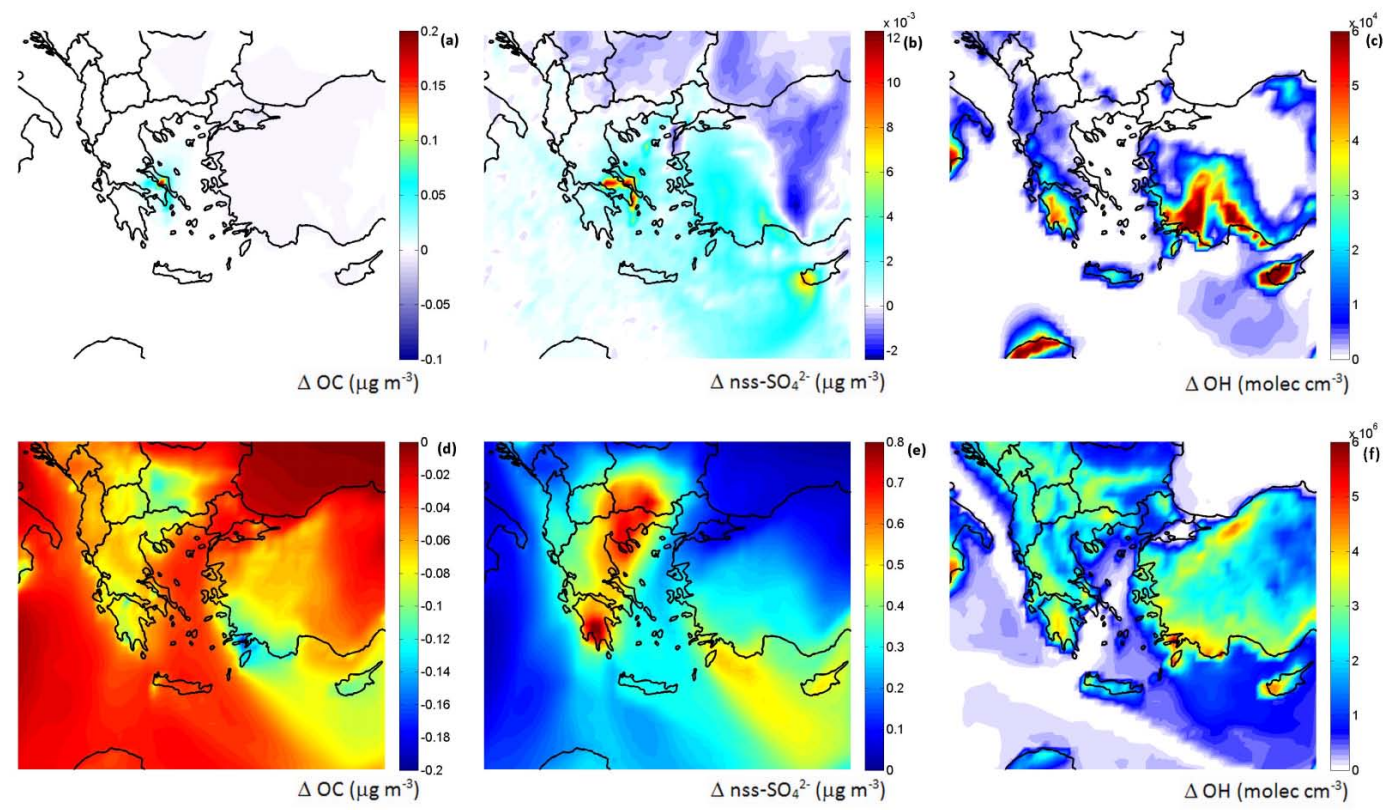

Fig. 5. Impact of biogenic emissions on surface levels of OC, nss- $\mathrm{SO}_{4}^{2-}$ and $\mathrm{OH}$, calculated as the difference of "NoBiog" simulations

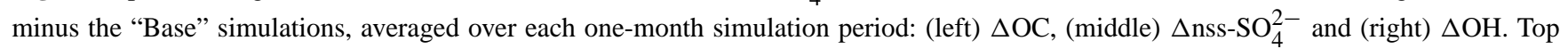

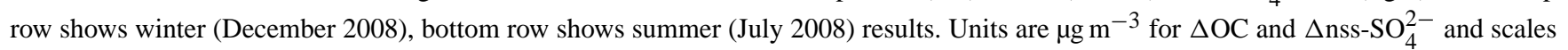
are different. For $\Delta \mathrm{OH}$ units are $10^{4} \mathrm{molec}^{-3}$ for (c) and $10^{6} \mathrm{molec} \mathrm{cm}^{-3}$ for (f).

$18 \%$ decrease of $\mathrm{O}_{3}$ over East Mediterranean in response to the $50 \%$ reductions of anthropogenic $\mathrm{NO}_{\mathrm{x}}$ over the entire Europe, recently calculated by Megaritis et al. (2012). Overall, the regional anthropogenic emissions can have a domain-mean impact up to $\sim 90 \%$, depending on the pollutant. $\mathrm{PM}_{2.5}$ percent reductions in summer are also comparable with those in winter (Table 5). These contributions are of the same magnitude with the impact of boundary conditions for the region (discussed in Sect. 2.2, see Table S4). In particular for $\mathrm{O}_{3}$, the responses of the domain-mean levels of $\mathrm{O}_{3}(30-50 \%)$ to the boundary condition perturbations are higher than those to the emission perturbations (4-17\%), indicating the importance of long range transport for $\mathrm{O}_{3}$ levels in the region, The results (Table $\mathrm{S} 4$ ) show that gaseous pollutants with lifetimes of several days to weeks, particularly $\mathrm{O}_{3}$, PAN, $\mathrm{CO}$ and $\mathrm{HNO}_{3}$, are most sensitive to long-range transport while the shorter-lived particulate pollutants are locallycontrolled.

It is worth discussing the impact of emissions from shipping on $\mathrm{O}_{3}$ surface levels over the sea southwest of Peloponnesus and of Crete, where the shipping tracks are marking $\mathrm{O}_{3}$ distribution (Figs. 2a and 3a). A corridor of lower $\mathrm{O}_{3}$ than in the surroundings is calculated for both seasons. Over the shipping tracks (as well as over GIA and GAA that are rich in $\mathrm{NO}_{\mathrm{x}}$ emissions) strong summertime diurnal variation in surface $\mathrm{O}_{3}$ is calculated as shown in Fig. S4 in the Supplement. For summer, our results show an increase in the daytime maximum surface $\mathrm{O}_{3}$ by shipping emissions as recently reported by Hodnebrog et al. (2012) indicating that sufficient NMVOC are available to fuel $\mathrm{O}_{3}$ production in this $\mathrm{NO}_{\mathrm{X}}$ rich environment. However, our results also show a stronger nighttime loss of $\mathrm{O}_{3}$. This is due to the reaction of $\mathrm{O}_{3}$ that is formed during day in the shipping plumes or is transported from upwind locations with NO that is emitted from shipping. $\mathrm{HNO}_{3}$ enhancement over shipping tracks also shows up in the computed surface $\mathrm{HNO}_{3}$ distribution in summer. Such a pattern is not evident in winter when removal of $\mathrm{HNO}_{3}$ by deposition is important (not shown). In the absence of regional anthropogenic emissions, including shipping, less $\mathrm{O}_{3}$ is formed in the region and transported from upwind locations and, on the other hand, $\mathrm{O}_{3}$ titration does not occur over the shipping tracks. Overall, in winter $\mathrm{O}_{3}$ is higher there in the "NoAnth" compared to the "Base" case by about 2 ppbv (Fig. 2e) because the titration effect is higher than the $\mathrm{O}_{3}$ build up. On the opposite in summer, the reduction in the regional background of $\mathrm{O}_{3}$ and its precursors in the "NoAnth" simulation (Fig. 3e) is very high and is not compensated by the absence of $\mathrm{O}_{3}$ titration over the shipping tracks. Thus, a decrease in $\mathrm{O}_{3}$ is computed in the "NoAnth" compared to the "Base" simulation.

In conclusion, the regional anthropogenic emissions contribution to pollutant levels is calculated to be much higher than that of the regional biogenic emissions, indicating the importance of anthropogenic emissions for air quality in the area, particularly in summer. 


\subsection{Impacts of megacity emissions}

\subsubsection{Gases}

The impacts of Athens and Istanbul emissions, individually (Fig. S5 in the Supplement) and combined (Fig. 6), on the spatial distributions of winter and summer mean surface $\mathrm{O}_{3}$ and $\mathrm{PM}_{2.5}$ concentrations in the studied region are calculated by subtracting the results of the Base simulation from those of the simulations "NoIst", "NoAth" and "NoIstAth", respectively (Table S5 reports the domain mean values at surface for all simulations). The percent changes in the major gas and aerosol component concentrations in the cities, at FKL and in the model domain for these scenarios with respect to the "Base" simulation are also provided in Table 5 for winter and summer. Significant fractions of the surface mixing ratio of $\mathrm{CO}$ in both cities are associated with the anthropogenic emissions of the cities themselves (23-39\% in GIA and 39-43\% in GAA) with higher contributions in winter. When omitting the anthropogenic emissions of both GIA and GAA, $\mathrm{NO}_{\mathrm{x}}$ is drastically reduced in the extended areas (89-93\% in winter and $92-96 \%$ in summer) with the highest reductions in GIA.

In winter, both cities have a larger impact northward due to the prevailing southerly winds (Fig. $2 \mathrm{~g}$, h). Thus, GIA impacts the western Black Sea and to a lesser extent the Marmara Sea and the Northern Aegean Sea. GAA impacts largely towards the Northern Aegean Sea and less towards Peloponnesus that is situated south-westward. On the other hand, in summer, both cities have a pronounced southward outflow (Fig. 3g, h). GIA emissions show a large outflow towards the south, mostly over the Marmara Sea and the Northern Aegean but also extending to the East Mediterranean Sea while GAA has a clear effect on the southern Aegean and East Mediterranean (Figs. 2g, 3g). Omission of anthropogenic emissions lowers the $\mathrm{NO}_{\mathrm{x}}$ levels, and thus the $\mathrm{O}_{3}$ loss by reaction with NO. It also increases the $\mathrm{NMVOC} / \mathrm{NO}_{\mathrm{x}}$ ratio favoring $\mathrm{NMVOC}$ oxidation to fuel $\mathrm{O}_{3}$ production than the reaction of $\mathrm{NO}_{2}$ with $\mathrm{OH}$ to form $\mathrm{HNO}_{3}$. Thus, it leads to an increase in $\mathrm{O}_{3}$ in the urban areas (Table 5). Because of the intensive photochemistry in the region and the relatively coarse model grid, NO-titration is not the only mechanism acting on $\mathrm{O}_{3}$ levels in urban areas. This is also suggested by the change in the sum of $\mathrm{O}_{3}$ and $\mathrm{NO}_{2}$ concentrations in the urban GIA and GAA areas by 10 $20 \%$ in winter and by $7 \%$ in summer. As shown in Fig. 4, when GAA and GIA anthropogenic emissions are omitted in the "NoIstAth" case, the $\mathrm{NO}_{2}$ reactivity against $\mathrm{OH}$ radical is decreasing. In both cities, $\mathrm{NO}_{2}$ levels supported by atmospheric transport from upwind areas and biogenic emissions (Table 1) remain reasonably high to favor $\mathrm{O}_{3}$ formation (Lei et al., 2007). Therefore, in the absence of anthropogenic emissions, NMVOC oxidation in the urban areas is enhanced and produces hydroperoxy $\left(\mathrm{HO}_{2}\right)$ radicals. Overall, monthlymean $\mathrm{HO}_{2}$ levels increase by $\sim 80 \%$ to $\sim 120 \%$ in GIA and $\sim 30 \%$ to $\sim 40 \%$ in GAA during summer and win- ter, respectively. This favors $\mathrm{HO}_{2}$ reaction with $\mathrm{NO}$ during NMVOC oxidation and thus increases the efficiency of the remaining $\mathrm{NO}_{\mathrm{x}}$ molecules to produce $\mathrm{O}_{3}$ (Lin et al., 1988; Finlayson-Pitts and Pitts, 2000).

In winter, the GIA anthropogenic emissions depress the surface PAN levels by $3 \%$ in the entire GIA due to the above explained $\mathrm{O}_{3}$ titration and NMVOC oxidation suppression. In summer these emissions contribute by $8 \%$ to PAN levels because photochemistry is faster and biogenic NMVOC emissions are high, limiting the $\mathrm{NO}$ titration of $\mathrm{O}_{3}$ and enhancing the $\mathrm{O}_{3}$ and PAN production pathways of NMVOC oxidation chains (Table 5). In GAA extended area, the GAA anthropogenic contribution increases PAN by $0.5 \%$ in winter and by $28 \%$ in summer. The differences in the impact of the anthropogenic emissions in GIA and GAA can be explained by the larger reduction in $\mathrm{OH}$ radical in GIA than in GAA (Table 5). Masking anthropogenic emissions of GIA results in a very large increase in $\mathrm{O}_{3}$ mixing ratios in the urban areas by $20 \mathrm{ppbv}(238 \%)$ in winter and by $27 \mathrm{ppbv}(81 \%)$ in summer (Figs. $2 \mathrm{~g}$ and $3 \mathrm{~g}$; Fig. S5 in the Supplement shows results for the "NoIst" and "NoAth" simulations). The impact on the entire GIA is lower ( $\sim 11$ ppbv both in winter $(61 \%)$ and in summer (22\%)). When masking the GAA emissions (Fig. S5c, d, g, h) an increase in $\mathrm{O}_{3}$ by 8 ppbv $(\sim 30 \%)$ in the city itself is computed in winter (Table 5) whereas in summer, the emissions have opposite impact on $\mathrm{O}_{3}$ increasing by $5 \mathrm{ppbv}(8 \%)$ the mean surface $\mathrm{O}_{3}$ levels in the GAA. The smaller effect of city emissions in GAA compared to GIA is due to the higher background levels of pollution in Athens than in Istanbul (Im et al., 2011; Kanakidou et al., 2011) as discussed earlier. It is also due to a larger change in the NMVOC $/ \mathrm{NO}_{\mathrm{x}}$ emission molar ratios in GIA when anthropogenic emissions are masked (from about 0.4 to 23.4 in winter and about 0.4 to 64.6 in summer) compared to that in GAA (from about 1.8 to 20.1 in winter and about 2.1 to 47.8 in summer, respectively; Table 1). These ratios are higher when only biogenic emissions are taken into account and lower when both anthropogenic and biogenic emissions are considered due to the strong anthropogenic sources of $\mathrm{NO}_{\mathrm{x}}$ and biogenic sources of NMVOC. Thus, computed changes in the $\mathrm{NO}_{2}$ and integrated $\mathrm{NMVOC}$ reactivity against $\mathrm{OH}$ are larger in GIA than in GAA (Fig. 4).

GIA and GAA outflows also affect the $\mathrm{O}_{3}$ mixing ratios downwind. In winter, both GIA and GAA anthropogenic emissions have negative contribution to $\mathrm{O}_{3}$ at downwind locations since under their influence high amounts of NO emitted in the cities are finally converted to $\mathrm{HNO}_{3}$ and do not produce $\mathrm{O}_{3}$. In addition, in winter the cities outflow patterns (Fig. $2 \mathrm{~g}, \mathrm{~h}$ ) that are driven by the dominant winds show relatively short spatial-range impacts of these emissions mainly over the West Black Sea and the North Aegean. Contrary, in summer (Fig. 3g, h) when both chemistry and atmospheric transport are faster, the cities outflows are oriented southward over the East Mediterranean and increase the regional background in the region. Im et al. (2011) indicated that in 

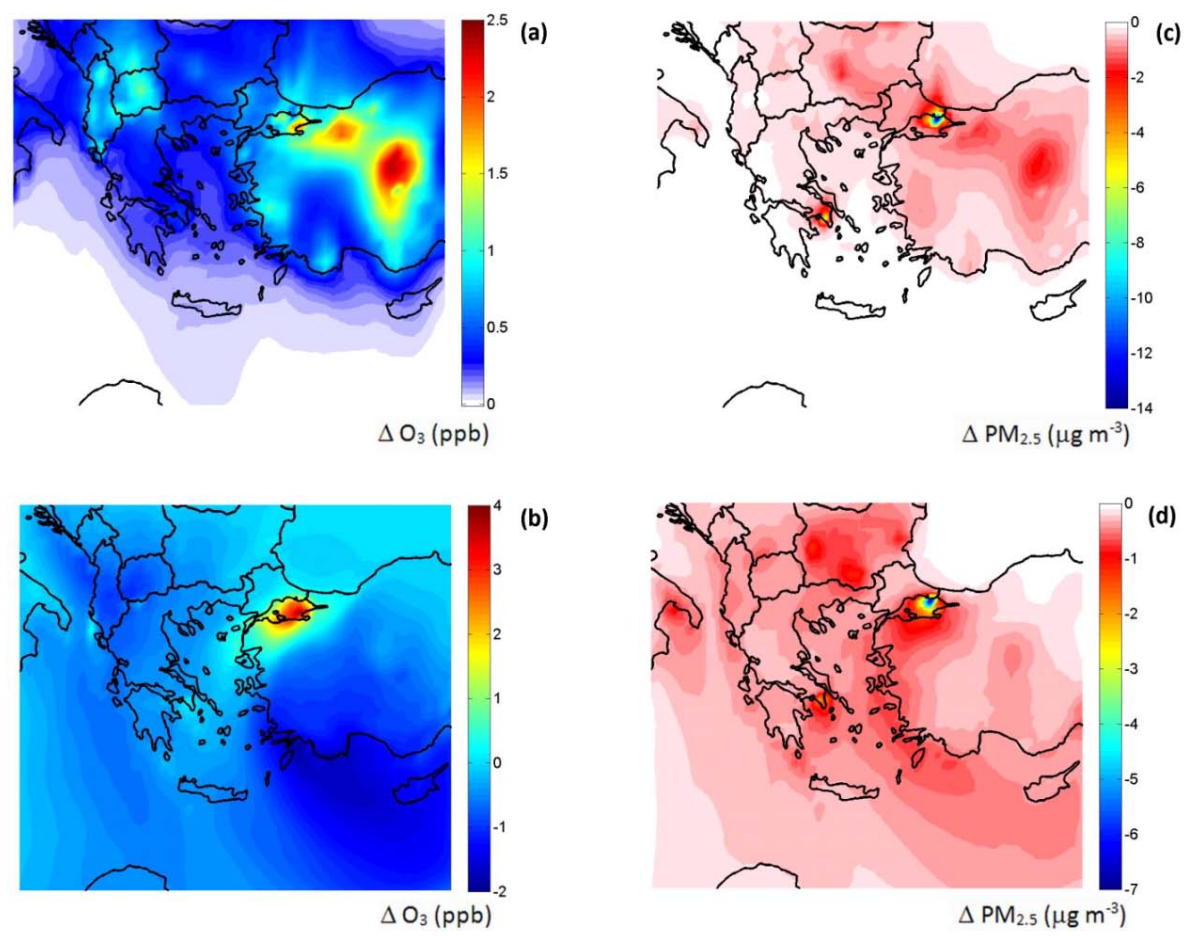

Fig. 6. Regional changes in surface levels of $\mathrm{O}_{3}$ (left panels) and $\mathrm{PM}_{2.5}$ (right panels) due to the mitigation of anthropogenic emissions (Mitig), calculated as the difference of "Mitig" minus "Base" results and averaged over each one-month simulation period in winter (December 2008 ; a, c) and summer (July 2008 ; b, d). Units are ppbv for $\Delta \mathrm{O}_{3}$ and $\mu \mathrm{g} \mathrm{m}^{-3}$ for $\Delta \mathrm{PM}_{2.5}$.

summer GIA urban areas act as a chemical sink for $\mathrm{O}_{3}$ due to the high $\mathrm{NO}_{\mathrm{x}}$ emissions as shown in Table 1. As explained above, GIA anthropogenic emissions have a negative contribution to the $\mathrm{O}_{3}$ levels at FKL $(0.2 \mathrm{ppbv}$ that is $0.5 \%)$ in winter and a positive contribution ( $1 \mathrm{ppbv}$, i.e. $1.5 \%)$ in summer. GIA anthropogenic emissions also contribute by $0.8 \%$ and $0.4 \%$ to the $\mathrm{O}_{3}$ mixing ratios in GAA in winter and summer, respectively. Anthropogenic emissions of both urban agglomerations (NoIstAth) depress by $0.4 \mathrm{ppbv}(1.3 \%)$ the domain mean surface $\mathrm{O}_{3}$ mixing ratios in winter and increase it by $0.4 \mathrm{ppbv}(0.7 \%)$ in summer (Table 5 ). The urban centers are mainly affected by their own emissions. Athens air pollution further benefits from reduction in GIA anthropogenic emissions in summer since GIA emissions contribute to the elevated background air pollution levels in GAA.

It is worth comparing the impacts of GIA and GAA anthropogenic emissions as deduced from the "NoIstAth" simulations with these of the entire anthropogenic emissions in the model domain ("NoAnth"; Table 5) taking into account the contribution of the hot spot emissions to the regional anthropogenic emissions (Table 1). Such comparison can provide hints on the importance for the air quality in the region of the concentration of emissions in hot spot areas. Impacts of regional anthropogenic emissions on the domain-mean surface pollutant levels (up to $17 \%$ for summertime $\mathrm{O}_{3}$ and up to $52 \%$ for wintertime $\mathrm{PM}_{2.5}$ ) are much higher than those from GIA and GAA together $\left(\sim 1 \%\right.$ for $\mathrm{O}_{3}$ and $\sim 6 \%$ for
$\mathrm{PM}_{2.5}$, respectively). However, during winter the concentration of the $\mathrm{NO}_{\mathrm{x}}$ emissions in the hot spot regions is shown to enhance their impact on the domain mean levels of $\mathrm{NO}_{\mathrm{x}}$ and $\mathrm{HNO}_{3}$ whereas this is not the case for summertime emissions.

\subsubsection{Particulate matter}

Anthropogenic emissions from GIA have a larger influence on the aerosol mass concentrations and chemical composition in the area and downwind than those from GAA, both in terms of the area influenced and the magnitude of the impact (Figs. 2h, 3h, see also Fig. S5 in the Supplement for individual hot spot impacts and Table 5 for percent changes).

Wintertime anthropogenic emissions of GIA are responsible for $24 \mu \mathrm{g} \mathrm{m}^{-3}(\sim 85 \%)$ of the calculated $\mathrm{PM}_{2.5}$ levels in its urban areas and $6 \mu \mathrm{g} \mathrm{m}^{-3}(60 \%)$ in its rural suburbs (Table 5), whereas the summertime contributions are lower, being $12 \mu \mathrm{g} \mathrm{m}^{-3}(72 \%)$ in the urban and $1 \mu \mathrm{g} \mathrm{m}^{-3}(21 \%)$ in the rural areas of GIA (Table 5). Overall, a 50-74\% contribution of anthropogenic emissions of GIA to the $\mathrm{PM}_{2.5}$ surface levels in the extended area of GIA is computed for summer and winter, respectively. For GAA anthropogenic emissions this contribution is $37 \%$ and $75 \%$ for summer and winter, respectively. Furthermore, masking the GAA anthropogenic emissions results in a $17 \mu \mathrm{g} \mathrm{m}^{-3}(88 \%)$ reduction in surface $\mathrm{PM}_{2.5}$ in the urban Athens area and $6 \mu \mathrm{g} \mathrm{m}^{-3}(72 \%)$ in the 
rural areas in winter, while in summer anthropogenic emissions of GAA contribute by $8 \mu \mathrm{g} \mathrm{m}^{-3}(59 \%)$ in the urban and $1 \mu \mathrm{g} \mathrm{m}^{-3}(15 \%)$ in the rural areas. Worth noting is also that in summer, GIA anthropogenic emissions have a contribution of $0.06 \mu \mathrm{g} \mathrm{m}^{-3}(1 \%)$ to the $\mathrm{PM}_{2.5}$ levels in GAA whereas GAA has almost no effect on the GIA levels (less than $-0.1 \%$ ). The wintertime percent contribution of the anthropogenic emissions from GIA to the domain-mean surface $\mathrm{PM}_{2.5}$ levels (4\%) is larger than that from GAA (2\%) while both have similar contributions to $\mathrm{PM}_{2.5}$ at the downwind location of FKL $(1 \%)$. The summertime percent contributions to surface $\mathrm{PM}_{2.5}$ at FKL are higher (7\% for GIA and $2 \%$ for GAA) while domain-mean contributions remain similar to those in winter.

Domain-wide, surface nss- $\mathrm{SO}_{4}^{2-}$ levels experience a larger reduction (4\% in summer and $1 \%$ in winter) when GIA anthropogenic emissions are masked compared to the impact of GAA emissions ( $\sim 1 \%$ in both seasons). These impacts on secondary aerosol components integrate changes in the aerosol precursors (e.g. $\mathrm{SO}_{2}$ emissions) as well as in the oxidant levels. Wintertime simulations show a large primary origin of OC in GIA and GAA, with contributions of cities emissions by $\sim 80 \%\left(3 \mu \mathrm{g} \mathrm{m}^{-3}\right.$ and $2 \mu \mathrm{g} \mathrm{m}^{-3}$, in their extended areas, respectively) in agreement with observations by Theodosi et al. (2010), Koçak et al. (2011) and Grivas et al. (2012). Summertime contributions are smaller (65\% in GIA and $22 \%$ in GAA) suggesting increased importance of SOA and atmospheric transport from upwind areas. A maximum contribution of GIA to OC levels at FKL of $7 \%$ is calculated while GAA impact is small $(\sim 1 \%)$. Domain-wide, GIA and GAA emissions contribute by $5 \%$ and $3 \%$ to the OC levels in winter and by $4 \%$ and $<1 \%$ in summer, respectively. For EC, cities anthropogenic emissions contribute by $77 \%\left(1.2 \mu \mathrm{g} \mathrm{m}^{-3}\right)$ and $61 \%\left(0.3 \mu \mathrm{g} \mathrm{m}^{-3}\right)$ to the wintertime levels over GIA and GAA respectively; smaller contributions are calculated for summer $\left(67 \%\left(0.5 \mu \mathrm{g} \mathrm{m}^{-3}\right)\right.$ in GIA and $47 \%\left(0.24 \mu \mathrm{g} \mathrm{m}^{-3}\right)$ in GAA $)$.

Furthermore, the impacts of anthropogenic emissions of PM and their precursors concentrated in the hot spots of GIA and GAA (NoIstAth) are compared to those of the total regional anthropogenic emissions (NoAnth) (Table 5) taking into account the contribution of the hot spot emissions to the regional anthropogenic emissions (Table 1). This comparison shows that the concentration of the $\mathrm{PM}_{2.5}$ anthropogenic emissions in the hot spot areas does not significantly affect the impact of these emissions on the domain mean $\mathrm{PM}_{2.5}$ levels although a small environmental gain is computed $(<15 \%)$ with regard to $\mathrm{PM}_{2.5}$ domain mean levels at surface.

\subsection{Impact of mitigation on air quality}

The impacts of the mitigation scenario (Mitig; Table 1) on the wintertime and summertime $\mathrm{O}_{3}$ and $\mathrm{PM}_{2.5}$ levels at surface are presented in Fig. 6. As explained in Sect. 2.2, these calculations assume no change in the boundary conditions of the model compared to the "Base" simulations, thus, implying no mitigation out of the model domain. Although, accounting for changing boundary conditions due to mitigation of emissions outside of the model domain would provide more "realistic" results, such study would require mitigation simulations with a larger scale model with zooming capabilities that is out of the scope of the present study. Simulation "Mitig" can provide useful information on the potential efficiency only of measures taken inside the region. Table S6 in the Supplement summarizes the computed changes in the main pollutants and chemical indicators in GIA, GAA and the region. Impacts in winter are different from those in summer, particularly for $\mathrm{O}_{3}$.

Unfortunately, the investigated country-based emissions mitigation inside the studied region does not appear sufficient to suppress $\mathrm{O}_{3}$ levels due to the non-linear chemical response of $\mathrm{O}_{3}$ to $\mathrm{NO}_{\mathrm{x}}$ reductions, discussed in Sects. 3.3 and 3.4.1. Surface $\mathrm{O}_{3}$ levels are computed to increase domainwide by less than $1 \%$ in winter, with changes higher than 2 ppbv over central Turkey (Fig. 6a) and also significant increases in the urban areas of the cities (1.1 ppbv: $13 \%$ in GIA and 0.4 ppbv: $2 \%$ in GAA; Fig. S6a, c). In summer, surface $\mathrm{O}_{3}$ are projected to decrease domain-wide except in GIA and GAA outflows. Thus, summertime $\mathrm{O}_{3}$ increases (Table S6) of $2.3 \mathrm{ppbv}$ and up to $4 \mathrm{ppbv}$ are calculated for GIA urban areas and over the Marmara Sea, respectively (Fig. S6e). $\mathrm{O}_{3}$ increases smaller than $0.5 \mathrm{ppbv}$ are computed over southeast Attica and the Saronikos Sea downwind GAA (Fig. S6g). Overall, a very small environmental gain of $0.5 \mathrm{ppbv}(1 \%)$ reduction is calculated for the domain mean surface $\mathrm{O}_{3}$. Winter levels of other gaseous pollutants are projected to decrease (Table S6). CO levels are reduced by 3 ppbv ( $2 \%)$ averaged in the entire region, with the largest reduction in the urban areas (74 ppbv $(20 \%)$ in GIA and 19 ppbv $(5 \%)$ in GAA). Smaller reductions are computed for CO levels in summer. $\mathrm{NO}_{\mathrm{x}}$ levels decrease by $\sim 4 \%$ (up to $1.5 \mathrm{ppbv}$ in GAA) to $\sim 16 \%$ (up to $20 \mathrm{ppbv}$ in GIA) depending on location (Table S6). Significant reductions in winter are also computed for surface PAN levels whereas in summer PAN shows similar behavior with $\mathrm{O}_{3}$, with increases over GIA and the Marmara region (up to $2 \%$ not shown). Larger reductions are calculated for the central and south-western Turkey as well as over Albania and Serbia. Overall, PAN levels decrease in the studied domain (by $3 \%$ ).

Mitigation appears more efficient for particulate pollutants since wintertime surface $\mathrm{PM}_{2.5}$ levels decrease over GIA and to a lesser extent over GAA (Fig. 6c, d). The largest $\mathrm{PM}_{2.5}$ reductions are computed to occur in the urban areas $\left(8 \mu \mathrm{g} \mathrm{m}^{-3}\right.$ : $30 \%$ in GIA and $4 \mu \mathrm{g} \mathrm{m}^{-3}: 20 \%$ in GAA) whereas a domainwide $0.3 \mu \mathrm{g} \mathrm{m}^{-3}(10 \%)$ reduction can be achieved. Among the aerosol species, the highest percent reductions are projected for OC and EC, due to the mitigation ratios applied to their emissions that decrease by $\sim 70 \%$ for $\mathrm{OC}$ and $\sim 60 \%$ for EC in the domain (Table S2). In the GIA, OC and EC are 
reduced by 1.3 and $0.7 \mu \mathrm{g} \mathrm{m}^{-3}$ ( $42 \%$ both) while in GAA the reductions are $0.9 \mu \mathrm{g} \mathrm{m}^{-3}$ (39\%) and $0.2 \mu \mathrm{g} \mathrm{m}^{-3}$ (37\%), respectively. For summer significant reductions in $\mathrm{PM}_{2.5}$ levels are computed due to emission mitigation (Fig. 6d). Reductions as important as $3.9 \mu \mathrm{g} \mathrm{m}^{-3}(24 \%)$ are projected for the urban areas in GIA and $1.5 \mu \mathrm{g} \mathrm{m}^{-3}(17 \%)$ when the entire GIA area is considered. GAA is expected to experience lower but also significant reductions of $\sim 1.3 \mu \mathrm{g} \mathrm{m}^{-3}(10 \%)$ in the urban areas and $\sim 0.7 \mu \mathrm{g} \mathrm{m}^{-3}(8 \%)$ when the whole extended area is accounted. The largest reductions are calculated for $\mathrm{OC}$ and EC, as was in the case in winter. They are $\sim 30 \%$ for GIA, $20-30 \%$ for GAA and $\sim 15 \%$ for the downwind remote locations in the region. As earlier discussed nss$\mathrm{SO}_{4}^{2-}$ are mainly of secondary origin therefore these changes integrate those in the emissions of their precursor $(<1 \%$, Table 1 and Table S2) and in the oxidant levels. Therefore, they are computed to decrease by only a few $\%$ (1\% in GIA, $3 \%$ in GAA and $3 \%$ in the domain mean levels). For the same reasons, computed changes for $\mathrm{NO}_{3}^{-}$are larger $(3 \%$ in the domain mean levels) since $\mathrm{NO}_{\mathrm{x}}$ emissions are projected to decrease significantly (Table 1).

In conclusion, the studied scenario of emissions mitigation applied only to the countries in the East Mediterranean, is expected to increase urban surface $\mathrm{O}_{3}$ both in winter and summer. In winter, $\mathrm{O}_{3}$ is expected to increase also domainwide whereas in summer a decrease in $\mathrm{O}_{3}$ levels is to be expected downwind, including the rural suburbs of Athens. Emission mitigation can be efficient for $\mathrm{PM}_{2.5}$ levels both in summer and winter. Environmental gain is higher in the cities themselves than at downwind locations. Secondary aerosols are more important downwind pollution sources and do not show clear behavior since they integrate the changes in the emissions and in tropospheric oxidants as above discussed for $\mathrm{O}_{3}$. It is worth mentioning that for the longer lived pollutants, the computed changes are smaller than those driven by long-range-transport changes, discussed in Sect. 3.1 based on the "Boundaries" scenario. This implies that improvements of air quality in the East Mediterranean require not only coordinated efforts inside the region but also beyond.

\section{Conclusions}

In the present study, WRF/CMAQ modeling system, coupled with the MEGAN biogenic emissions model, has been employed to investigate the impacts of East Mediterranean megacity emissions on the air quality of the cities and of the region for typical wintertime (December 2008) and summertime (July 2008) conditions. A number of emission scenarios have been applied over the extended areas of Istanbul and Athens to quantify the responses of urban and rural air quality to potential abatement strategies. GIA emissions have generally larger regional and downwind impacts on the gaseous pollutants than GAA emissions. Contributions from both cities to surface pollutant levels are generally higher in winter than in summer. Impacts of regional anthropogenic emissions on the domain-mean surface pollutant levels (up to $17 \%$ for summertime $\mathrm{O}_{3}$ and $52 \%$ for wintertime $\mathrm{PM}_{2.5}$ ) are much higher than those from GIA and GAA anthropogenic emissions together $\left(\sim 1 \%\right.$ for $\mathrm{O}_{3}$ and $\sim 6 \%$ for $\mathrm{PM}_{2.5}$, respectively). However, the strong concentration of the pollutant emissions in the hot spot regions is shown to enhance $\mathrm{NO}_{\mathrm{x}}$ emissions impact on the domain mean levels of $\mathrm{NO}_{\mathrm{x}}$ and $\mathrm{HNO}_{3}$ during winter, whereas this is not the case for summertime emissions. For surface $\mathrm{PM}_{2.5}$, small but not significant environmental gain is computed for the entire region when pollutant emissions are concentrated in the hot spots. Biogenic emissions have a limiting effect on the aerosol formation in the region during summer while in winter, the impact is negligible due to considerably lower biogenic emissions.

Mitigation of anthropogenic emissions based on IIASAprovided country-based ratios is calculated to result in domain-mean surface $\mathrm{O}_{3}$ mixing ratios by $\sim 1 \%$ higher in winter and lower in summer. Urban increases are large in Istanbul (13\% and $7 \%$ in winter and summer, respectively) while in Athens, they are $2 \%$ in winter and less than $1 \%$ in summer. Significant reductions are calculated for pollutants dominated by primary emissions like CO in GIA ( $15 \%$ in winter and $7 \%$ in summer). In GAA, CO levels are reduced by about $3 \%$ in both seasons. Wintertime $\mathrm{PM}_{2.5}$ levels decrease by up to $30 \%$ and $20 \%$ in the urban areas of GIA and GAA, respectively. In summer, the reductions are smaller, being $\sim 24 \%$ for GIA and $\sim 10 \%$ for GAA. Domain-mean $\mathrm{PM}_{2.5}$ levels are projected to decrease by $\sim 10 \%$ in winter and $\sim 6 \%$ in summer.

The results point out improvements for some gaseous and several aerosol species in the urban areas of the cities, which could decrease the exceedences and the human exposure. Thus, mitigation can be efficient for pollutants that are mostly of primary origin like $\mathrm{CO}$ and $\mathrm{PM}_{2.5}$ but the system is more complex for secondary pollutants and in particular for $\mathrm{O}_{3}$ due to the non-linear behavior of the chemistry of $\mathrm{O}_{3}-$ $\mathrm{NO}_{\mathrm{x}}$-NMVOC system as above discussed. The results show that the impact of long range transport is significant in the region, even higher than the contributions of the local anthropogenic emissions and therefore, should be considered when quantifying and evaluating the impacts of emissions and mitigation. Due to the non-linear responses of air pollution levels to the emission changes, higher spatial resolution and longer simulations that also include sector-based evaluations are needed to increase the robustness of the results presented in this study.

\section{Supplementary material related to this article is available online at: http://www.atmos-chem-phys.net/12/ 6335/2012/acp-12-6335-2012-supplement.pdf.}


Acknowledgements. This work has been performed in the frame of the CityZen project (European Union Seventh Framework Programme Grant Agreement no. 212095). Regional Emissions were derived from the continental scale EMEP/INERIS inventory provided by G. Siour (LISA/IPSL/INERIS) and B. Bessagnet (INERIS). We thank N. Daskalakis for providing chemical boundary conditions from the TM4-ECPL global model, K. Markakis for the anthropogenic emission inventories, M. Vrekoussis for compilation of observations in Athens and G. Kouvarakis for FKL observations. Ch. Heyes from IIASA is acknowledged for providing the mitigation ratios to the CityZen team. Fruitful scientific discussions with the CITYZEN group are acknowledged. We thank the reviewers for pertinent comments and for motivating us to largely improve the present work.

Edited by: L. Molina

\section{References}

Butler, T. M. and Lawrence, M. G.: The influence of megacities on global atmospheric chemistry: a modeling study, Environ. Chem., 6, 219-225, 2009.

Butler, T. M., Lawrence, M. G., Gurjar, B. R., van Aardenne, J., Schultz, M., and Lelieveld, J.: The representation of emissions from megacities in global emission inventories, Atmos. Environ., 42, 703-719, 2008.

CARB: Speciation Profiles Used in CARB Modeling, California Air Resources Board, Sacramento, California, 2007.

Carlton, A. G., Bhave, P. V., Napelenok, S. L., Edney, E. O., Sarwar, G., Pinder, R. W., Pouliot, G. A., and Houyoux, M.: Model representation of secondary organic aerosol in CMAQv4.7, Environ. Sci. Technol., 44, 8553-8560, 2010.

Chen, F. and Dudhia, J.: Coupling an advanced landsurface/hydrology model with the Penn State/ NCAR MM5 modeling system. Part I: model description and implementation, Mon. Weather Rev., 129, 569-585, 2001.

Dudhia, J.: Numerical study of convection observed during the winter monsoon experiment using a mesoscale two-dimensional model, J. Atmos. Sci., 46, 3077-3107, 1989.

Finlayson-Pitts, B. J. and Pitts, J. N.: Chemistry of the Upper and Lower Atmosphere, Academic Press, New York, 2000.

Foley, K. M., Roselle, S. J., Appel, K. W., Bhave, P. V., Pleim, J. E., Otte, T. L., Mathur, R., Sarwar, G., Young, J. O., Gilliam, R. C., Nolte, C. G., Kelly, J. T., Gilliland, A. B., and Bash, J. O.: Incremental testing of the Community Multiscale Air Quality (CMAQ) modeling system version 4.7, Geosci. Model Dev., 3, 205-226, doi:10.5194/gmd-3-205-2010, 2010.

Gaffney, J. S., Marley, N. A., Cunningham, M. M., and Doskey, P. C.: Measurements of peroxyacyl nitrates (PANS) in Mexico City: Implications for megacity air quality impacts on regional scales, Atmos. Environ., 33, 5003-5012, 1999.

Gerasopoulos, E., Kouvarakis, G., Vrekoussis, M., Kanakidou, M., and Mihalopoulos, M.: Ozone variability in the marine boundary layer of the eastern Mediterranean based on 7-year observations, J. Geophys. Res., 110, D15309, doi:10.1029/2005JD005991, 2005.

Grivas, G., Cheristanidis, S., and Chaloulakou, A.: Elemental and organic carbon in the urban environment of Athens. Seasonal and diurnal variations and estimates of secondary organic carbon, Sci. Total Environ., 414, 535-545, 2012.

Guenther, A., Karl, T., Harley, P., Wiedinmyer, C., Palmer, P. I., and Geron, C.: Estimates of global terrestrial isoprene emissions using MEGAN (Model of Emissions of Gases and Aerosols from Nature), Atmos. Chem. Phys., 6, 3181-3210, doi:10.5194/acp-63181-2006, 2006.

Hodnebrog, Ø., Stordal, F., and Berntsen, Т. K.: Does the resolution of megacity emissions impact large scale ozone?, Atmos. Environ., 45, 6852-6862, 2011.

Hodnebrog, Ø., Solberg, S., Stordal, F., Svendby, T. M., Simpson, D., Gauss, M., Hilboll, A., Pfister, G. G., Turquety, S., Richter, A., Burrows, J. P., and Denier van der Gon, H. A. C.: A model study of the Eastern Mediterranean ozone levels during the hot summer of 2007, Atmos. Chem. Phys. Discuss., 12, 7617-7675, doi:10.5194/acpd-12-7617-2012, 2012.

Hofzumahaus, A., Rohrer, F., Lu, K., Bohn, B., Brauers, T., Chang, C. C., Fuchs, H., Holland, F., Kita, K., Kondo, Y., Li, X., Lou, S., Shao, M., Zeng, L., Wahner, A., and Zhang, Y.: Amplified Trace Gas Removal in the Troposphere. Science, 324, 17021704. doi:10.1126/science.1164566, 2009.

Hong, S.-Y. and Lim, J.-O.: The WRF Single-Moment 6-Class Microphysics Scheme (WSM6), J. Korean Meteor. Soc., 42, 129151, 2006.

Hong, S.-Y., Dudhia, J., and Chen, S.-H.: A revised approach to ice microphysical processes for the bulk parameterization of clouds and precipitation, Mon. Weather Rev., 132, 103-120, 2004.

Honore, C., Rouil, L., Vautard, R., Beekmann, M., Bessagnet, B., Dufour, A., Elichegaray, C., Flaud, J.-M., Malherbe, L., Meleux, F., Menut, L., Martin, D., Peuch, A., Peuch, V.-H., and Poisson, N.: Predictability of European air quality: Assessment of 3 years of operational forecasts and analyses by the PREV'AIR system, J. Geophys. Res., 113, D04301, doi:10.1029/2007JD008761, 2008.

Im, U., Tayanc, M., and Yenigun, O.: Interaction patterns of major photochemical pollutants in Istanbul, Turkey, Atmos. Res., 89, 382-390, 2008.

Im, U., Markakis, K., Unal, A., Kindap, T., Poupkou, A., Incecik, S., Yenigun, O., Melas, D., Theodosi, C., and Mihalopoulos, N.: Study of a winter PM episode in Istanbul using the high resolution WRF/CMAQ modeling system, Atmos. Environ., 44, 30853094, 2010.

Im, U., Markakis, K., Poupkou, A., Melas, D., Unal, A., Gerasopoulos, E., Daskalakis, N., Kindap, T., and Kanakidou, M.: The impact of temperature changes on summer time ozone and its precursors in the Eastern Mediterranean, Atmos. Chem. Phys., 11, 3847-3864, doi:10.5194/acp-11-3847-2011, 2011.

Im, U., Markakis, K., Koçak. M., Gerasopoulos, E., Daskalakis, N., Mihalopoulos, N., Poupkou, A., Kindap, T., Unal, A., and Kanakidou, M.: Summertime aerosol chemical composition in the Eastern Mediterranean and its sensitivity to temperature: A modeling case study, Atmos. Environ., 50, 164-173, 2012.

Jimenez, P., Jorba, O., Parra, R., and Baldasano, J. M.: Influence of high model-grid resolution on photochemical modelling in very complex terrains, Int. J. Environ. Pollut., 24, 180-200, 2005.

Kain, J. S.: The Kain-Fritsch convective parameterization: An update, J. Appl. Meteorol., 43, 170-181, 2004.

Kanakidou, M. and Crutzen, P. J.: The photochemical source of carbon monoxide: Importance, Uncertainties and feedbacks, 
Chemosphere: Global Change Science, 1, 91-109, 1999.

Kanakidou, M., Mihalopoulos, N., Kindap, T., Im, U., Vrekoussis, M., Gerasopoulos, E., Dermitzaki, E., Unal, A., Kocak, M., Markakis, K., Melas, D., Kouvarakis, G., Youssef, A. F., Richter, A., Hatzianastassiou, N., Hilboll, A., Ebojie, F., von Savigny, C., Ladstaetter-Weissenmayer, A., Burrows, J., and Moubasher, H.: Megacities as hot spots of air pollution in the East Mediterranean. Atmos. Environ., 45, 1223-1235, 2011.

Kallos, G., Astitha, M., Katsafados, P., and Spyrou, C.: Long-range transport of anthropogenically and naturally produced particulate matter in the Mediterranean and North Atlantic: Current state of knowledge, J. Appl. Meteorol. Clim., 46, 1230-1251, 2007.

Kiendler-Scharr, A., Wildt, J., Maso, M. D., Hohaus, T., Kleist, E., Mentel., T., Tillmann, R., Uerlings, R., Schurr, U., and Wahner, A.: New particle formation in forests inhibited by isoprene emissions, Nature, 461, 381-384, doi:10.1038/nature08292, 2009.

Koçak, M., Theodosi, C., Theodosi C., Zarmpas, P., Im, U., Bougiatioti, A., Yenigun, O., and Mihalopoulos, N.: Particulate matter $\left(\mathrm{PM}_{10}\right)$ in Istanbul: Origin, source areas and potential impact on surrounding regions, Atmos. Environ., 45, 6891-6900, 2011.

Konovalov, I. B., Beekmann, M., Kuznetsova, I. N., Yurova, A., and Zvyagintsev, A. M.: Atmospheric impacts of the 2010 Russian wildfires: integrating modelling and measurements of an extreme air pollution episode in the Moscow region, Atmos. Chem. Phys., 11, 10031-10056, doi:10.5194/acp-11-10031-2011, 2011.

Kouvarakis, G., Bardouki, H., and Mihalopoulos, N.: Sulfur budget above the Eastern Mediterranean: Relative contribution of anthropogenic and biogenic sources, Tellus, 54B, 201-212, 2002.

Lawrence, M. G., Butler, T. M., Steinkamp, J., Gurjar, B. R., and Lelieveld, J.: Regional pollution potentials of megacities and other major population centers, Atmos. Chem. Phys., 7, 39693987, doi:10.5194/acp-7-3969-2007, 2007.

Lei, W., de Foy, B., Zavala, M., Volkamer, R., and Molina, L. T.: Characterizing ozone production in the Mexico City Metropolitan Area: a case study using a chemical transport model, Atmos. Chem. Phys., 7, 1347-1366, doi:10.5194/acp-7-1347-2007, 2007.

Li, G., Zavala, M., Lei, W., Tsimpidi, A. P., Karydis, V. A., Pandis, S. N., Canagaratna, M. R., and Molina, L. T.: Simulations of organic aerosol concentrations in Mexico City using the WRFCHEM model during the MCMA-2006/MILAGRO campaign, Atmos. Chem. Phys., 11, 3789-3809, doi:10.5194/acp-11-37892011, 2011.

Lin, M., Holloway, T., Carmichael, G. R., and Fiore, A. M.: Quantifying pollution inflow and outflow over East Asia in spring with regional and global models, Atmos. Chem. Phys., 10, 42214239, doi:10.5194/acp-10-4221-2010, 2010.

Lin, X., Trainer, M., and Liu, S. C.: On the nonlinearity of the tropospheric ozone production, J. Geophys. Res., 93, 15789-15888, 1988.

Markakis, K., Poupkou, A., and Melas, D., Tzoumaka, P., and Petrakakis, M.: A computational approach based on GIS technology for the development of an anthropogenic emission inventory of gaseous pollutants in Greece, Water Air Soil Pollut., 207, 157180, 2010a.

Markakis, K., Poupkou, A., and Melas, D. and Zerefos, C.: A GIS based anthropogenic $\mathrm{PM}_{10}$ emission inventory for Greece, Atmos. Poll. Res., 1, 71-81, 2010 b.
Markakis, K., Im, U., Unal A., Melas, D., Yenigun, O., and Incecik, S.: Compilation of a GIS based high spatially and temporally resolved emission inventory for the greater Istanbul area, Atmos. Poll. Res., 3, 112-125, 2012.

Megaritis, A. G., Fountoukis, C., Charalampidis, P. E., Pilinis, C., and Pandis, S. N.: Response of fine particulate matter concentrations to changes of emissions and temperature in Europe, Atmos. Chem. Phys. Discuss., 12, 8771-8822, doi:10.5194/acpd12-8771-2012, 2012.

Messner, S. and Struberger, M.: User's Guide for MESSAGE III. Working Paper. Laxenburg, Austria, International Institute for Applied Systems Analysis (IIASA), WP-95-69, 1995.

Mlawer, E. J., Taubman, S. J., Brown, P. D., Iacono, M. J., and Clough, S. A.: Radiative transfer for inhomogeneous atmospheres: RRTM, a validated correlated-k model for the longwave, J. Geophys. Res., 102, 16663-16682, 1997.

Molina, L. T., Madronich, S., Gaffney, J. S., Apel, E., de Foy, B., Fast, J., Ferrare, R., Herndon, S., Jimenez, J. L., Lamb, B., Osornio-Vargas, A. R., Russell, P., Schauer, J. J., Stevens, P. S., Volkamer, R., and Zavala, M.: An overview of the MILAGRO 2006 Campaign: Mexico City emissions and their transport and transformation, Atmos. Chem. Phys., 10, 8697-8760, doi:10.5194/acp-10-8697-2010, 2010.

Myriokefalitakis, S., Tsigaridis, K., Mihalopoulos, N., Sciare, J., Nenes, A., Kawamura, K., Segers, A., and Kanakidou, M.: In-cloud oxalate formation in the global troposphere: a 3-D modeling study, Atmos. Chem. Phys., 11, 5761-5782, doi:10.5194/acp-11-5761-2011, 2011.

Nenes, A., Pandis, S. N., and Pilinis C.: ISORROPIA: A new thermodynamic equilibrium model for multiphase multicomponent inorganic aerosols, Aquat. Geochem., 4, 123-152, 1998.

Olivier, J. G. J., Berdowski, J. J. M., Bakker, J. A. H. W. J., Visschedijk, A. J. H., and Bloos, J.-P. J.: Applications of EDGAR. Including a description of EDGAR 3.0: reference database with trend data for 1970-1995, RIVM, Bilthoven, RIVM report no. $773301001 /$ NOP report no. 410200051 , available at: http:// www.rivm.nl/bibliotheek/rapporten/410200051.pdf, 2001.

Paraskevopoulou, D., Gerasopoulos, E., Liakakou, E., Gratsea, M., Zarmpas, P., Theodosi, C., and Mihalopoulos N.: Optical properties of aerosols over Athens, Greece, and their relation with chemical composition, $11^{\text {th }}$ International Conference on Meteorology, Climatology and Atmospheric Physics, COMECAP 2012, Athens 30 May-1 June 2012.

Parrish, D. D., Kuster, W. C., Shao, M., Yokouchi, Y., Kondo, Y., Goldan, P. D., de Gouw, J. A., Koike, M., and Shirai, T.: Comparison of air pollutant emissions among mega-cities, Atmos. Environ., 43, 6435-6441, 2009.

Pateraki, St., Assimakopoulos, V. D., Bougiatioti, A., Kouvarakis, G., Mihalopoulos, N., and Vasilakos, Ch.: Carbonaceous and ionic compositional patterns of fine particles over an urban Mediterranean area, Sci. Total Environ., 424, 251-263, 2012.

Pleim, J. E.: A combined local and nonlocal closure model for the atmospheric boundary layer. Part I: Model description and testing, J. Appl. Meteorol. Climatol., 46, 1383-1395, 2007.

Poupkou, A., Symeonidis, P., Lisaridis, I., Melas, D., Ziomas, I., Yay, O. D. and Balis, D.: Effects of anthropogenic emission sources on maximum ozone concentrations over Greece, Atmos. Res., 89, 374-381, 2008. 
Queen, A. and Zhang, Y.: Examining the sensitivity of MM5CMAQ predictions to explicit microphysics schemes and horizontal grid resolutions, Part III-The impact of horizontal grid resolution, Atmos. Environ., 42, 3869-3881, 2008.

Rappengluck, B., Melas, D., and Fabian, P.: Evidence of the impact of urban plumes on remote sites in the Eastern Mediterranean, Atmos. Environ., 37, 1853-1864, 2003.

Royer, P., Chazette, P., Sartelet, K., Zhang, Q. J., Beekmann, M., and Raut, J.-C.: Lidar-derived $\mathrm{PM}_{10}$ and comparison with regional modeling in the frame of the MEGAPOLI Paris summer campaign, Atmos. Chem. Phys. Discuss., 11, 11861-11909, doi:10.5194/acpd-11-11861-2011, 2011.

Shrivastava, M., Fast, J., Easter, R., Gustafson Jr., W. I., Zaveri, R. A., Jimenez, J. L., Saide, P., and Hodzic, A.: Modeling organic aerosols in a megacity: comparison of simple and complex representations of the volatility basis set approach, Atmos. Chem. Phys., 11, 6639-6662, doi:10.5194/acp-11-6639-2011, 2011.

Simpson, D., Fagerli, H., Jonson, J. E., Tsyro, S., Wind, P., and Tuovinen, J.-P.: Transboundary acidification, eutrophication and ground level ozone in Europe. PART I. Unified EMEP model description. EMEP Report 1/2003, Norwegian Meteorological Institute, ISSN 0806-4520, 104 pp., 2003.

Skamarock, W. C. and Klemp, J. B.: A time-split non-hydrostatic atmospheric model, J. Comput. Phys., 227, 3465-3485, 2008.

Taraborrelli, D., Lawrence, M. G., Crowley, J. N., Dillon, T. J., Gromov, S., Groß, C. B. M., Vereecken, L., and Lelieveld, J.: Hydroxyl radical buffered by isoprene oxidation over tropical forests, Nature Geosci., 5, 190-193, 2012.

Theodosi, C., Im, U., Bougiatuoti, A., Zarmpas, P., Yenigun, O., and Mihalopoulos N.: Aerosol chemical composition over Istanbul, Sci. Total Environ., 408, 2482-2491, 2010.
Thunis, P.: The influence of scale on modeled ground level $\mathrm{O}_{3}$ concentrations, Norwegian Meteorological Institute Research Report, EMEP/MSC-W Note 2/01, Copenhagen, Denmark, No. 57, p. 42, 2001.

Thunis, P., Rouil, L., Cuvelier, C., Stern, R., Kerschbaumer, A., Bessagnet, B., Chaap, M., Builtjes, P., Tarrason, L., Douros, J., Moussiopoulos, N., Pirovano, G., and Bedogni, M.: Analysis of model responses to emission-reduction scenarios within the CityDelta project, Atmos. Environ., 41, 208-220, 2007.

Tie, X., Madronich, S., Li, G., Ying, Z., Weinheimer, A., Apel, E., and Campos, T.: Simulation of Mexico City plumes during the MIRAGE-Mex field campaign using the WRF-Chem model, Atmos. Chem. Phys., 9, 4621-4638, doi:10.5194/acp-9-4621-2009, 2009.

United Nations Population Fund, UNFPA, State of the world population 2007: Unleashing the potential of urban growth, available at: http://www.unfpa.org/swp/2007/presskit/pdf/sowp2007_ eng.pdf, 2007.

Yamartino, R. J.: Nonnegative, conserved scalar transport using grid-cell-centered, spectrally constrained Blackman cubics for applications on a variable-thickness mesh, Mon. Weather Rev., 121, 753-763, 1993.

Yardwood, G., Rao, S., Yocke, M., and Whitten, G. Z.: Updates to the Carbon Bond chemical mechanism: CB05. Final Report to the US EPA, RT-0400675, 8 December 2005. 